Sustainable Agriculture Reviews 22

Eric Lichtfouse Editor

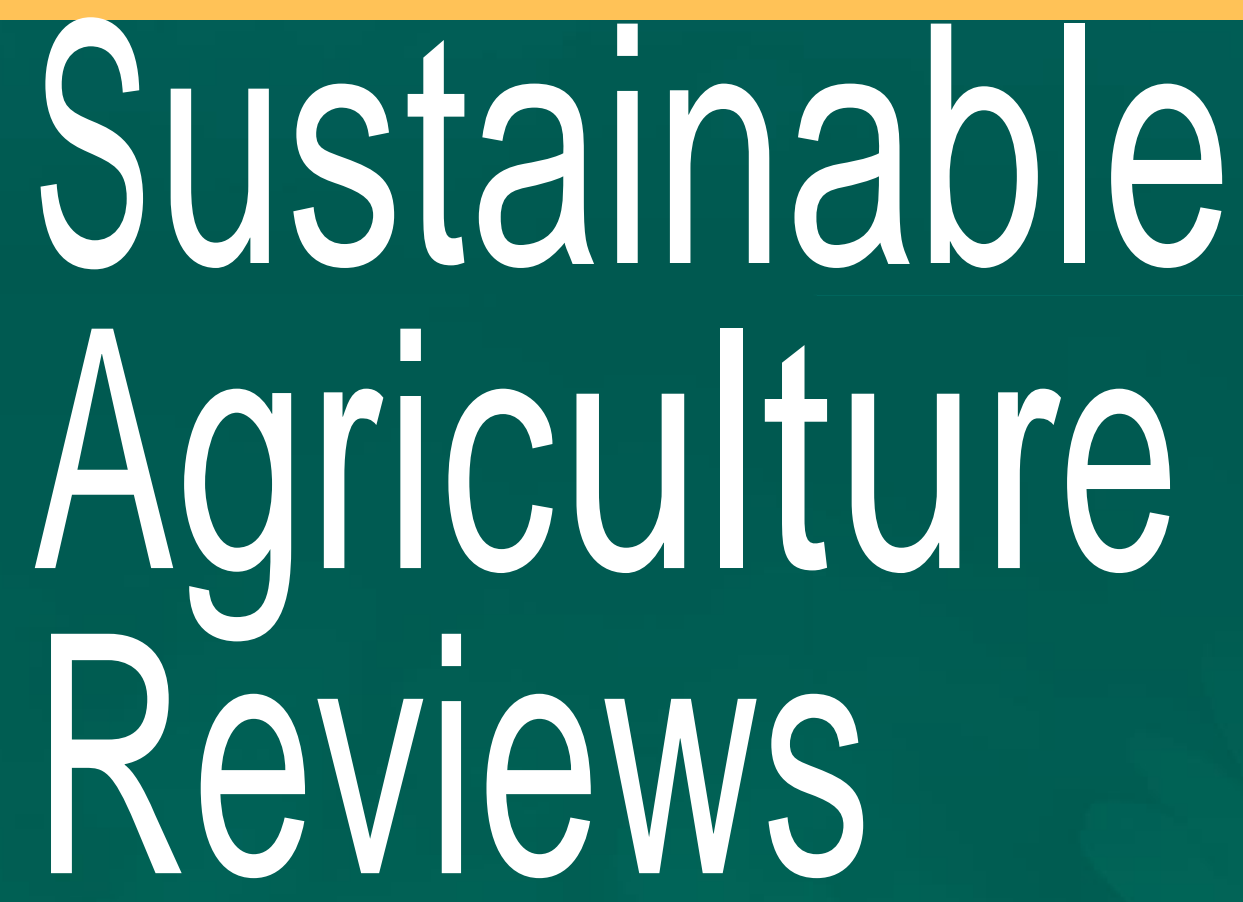

Springer 


\section{Sustainable Agriculture Reviews}

Volume 22

\section{Series editor}

Eric Lichtfouse 


\section{Books}

Scientific Writing for Impact Factor Journals

Nova Publishers 2013

Sustainable Agriculture

Springer 2009

Sustainable Agriculture Volume 2

Springer 2011

Environmental Chemistry. Green Chemistry and Pollutants in Ecosystems Springer 2005

Rédiger pour être publié ! Conseils pratiques pour les scientifiques Springer 2012, $2^{\mathrm{e}}$ édition.

\section{Journals and Series}

Agronomy for Sustainable Development

www.springer.com/journal/13593

Sustainable Agriculture Reviews

www.springer.com/series/8380

Environmental Chemistry Letters

www.springer.com/journal/10311

Environmental Chemistry for a Sustainable World www.springer.com/journal/11480

\section{Blog}

Agronomy blog

http://www1.montpellier.inra.fr/agronomy-blog

\section{Magazine}

Publier La Science

https://listes.inra.fr/sympa/d_read/veillecaps/

More information about this series at http://www.springer.com/series/8380 
Eric Lichtfouse

Editor

\section{Sustainable Agriculture Reviews}

望 Springer 


\section{Editor}

Eric Lichtfouse

CEREGE

INRA

Aix en Provence, France

ISSN 2210-4410

Sustainable Agriculture Reviews

ISBN 978-3-319-48005-3

DOI 10.1007/978-3-319-48006-0

\section{Library of Congress Control Number: 2016963152}

(C) Springer International Publishing Switzerland 2017

This work is subject to copyright. All rights are reserved by the Publisher, whether the whole or part of the material is concerned, specifically the rights of translation, reprinting, reuse of illustrations, recitation, broadcasting, reproduction on microfilms or in any other physical way, and transmission or information storage and retrieval, electronic adaptation, computer software, or by similar or dissimilar methodology now known or hereafter developed.

The use of general descriptive names, registered names, trademarks, service marks, etc. in this publication does not imply, even in the absence of a specific statement, that such names are exempt from the relevant protective laws and regulations and therefore free for general use.

The publisher, the authors and the editors are safe to assume that the advice and information in this book are believed to be true and accurate at the date of publication. Neither the publisher nor the authors or the editors give a warranty, express or implied, with respect to the material contained herein or for any errors or omissions that may have been made.

Printed on acid-free paper

This Springer imprint is published by Springer Nature

The registered company is Springer International Publishing AG

The registered company address is: Gewerbestrasse 11, 6330 Cham, Switzerland 


\section{Contents}

1 Animal Waste: Opportunities and Challenges ……………................. 1 Francesca Girotto and Raffaello Cossu

2 Soil Microorganisms Can Reduce P Loss from Cropping Systems

R. Michael Lehman and Wendy I. Taheri

3 Greenhouse Technology for Agriculture Under

Arid Conditions

Ellen Letsogile Thipe, Tilahun Workneh,

Alferd Odindo, and Mark Laing

4 Biochar for Agriculture in Pakistan

Fahd Rasul, Ashfaq Ahmad, Muhammad Arif, Ishaq Ahmad Mian, Kawsar Ali, Muhammad Farooq Qayyum, Qaiser Hussain, Muhammad Aon, Shahzad Latif, Ruben Sakrabani, Muhammad Saghir, Genxing Pan, and Simon Shackley

5 Effect of UV-B Radiation on Leguminous Plants. Krishna Kumar Choudhary and Shashi Bhushan Agrawal

6 Control of Fungal Diseases in Agricultural Crops by Chitinase and Glucanase Transgenes

Jagdeep S. Sandhu, Manpreet K. Sidhu, and Inderjit S. Yadav

7 Bioengineering Hairy Roots: Phytoremediation, Secondary Metabolism, Molecular Pharming, Plant-Plant Interactions and Biofuels

Peyman Habibi, Maria Fatima Grossi De Sa, Abdullah Makhzoum, Sonia Malik, André Luís Lopes da Silva, Kathleen Hefferon, and Carlos Ricardo Soccol 
8 Soil Management to Optimize Water in Rice-Wheat Cropping ........ 253 Jagdish Singh, Sandeep Singh Sandhu, Dhanwinder Singh, and Manjit Singh Hadda

9 Microbial Inoculants for Soil Quality and Plant Health 281 Elizabeth T. Alori, Michael O. Dare, and Olubukola O. Babalola

10 Conservation Agriculture in Tanzania 309 Msafiri Yusuph Mkonda and Xinhua He

Index 325 


\title{
Chapter 9 \\ Microbial Inoculants for Soil Quality and Plant Health
}

\author{
Elizabeth T. Alori, Michael O. Dare, and Olubukola O. Babalola
}

\begin{abstract}
Agriculture is the major economic activity of most developing countries engaging more than $50 \%$ of the population. Low world crop productivity due to low soil moisture, low nutrient capital, erosion risk, low $\mathrm{pH}$, high phosphorus fixation, low levels of soil organic matter, aluminum toxicity pest and diseases, weeds and loss of soil biodiversity has induced the green revolution agriculture which involves high yielding varieties and agrochemicals. The continuous use of fertilizers, pesticides and herbicides has led to low agricultural productivity, low soil fertility, unfavourable economic returns, food poisoning, soil damage loss of biodiversity and serious environmental hazards. Microbial inoculants possess the capacity to enhance nutrient availability, uptake, and support the health of soil and plants to promote sustainable yield and has therefore gained attention of many agriculturist and researchers.

We review the ability of soil through the use of microbial inoculants to supply nitrogen, phosphorus and potassium to crop plants and enhance structural stability. Microbial inoculants such as rhizobium, plant growth promoting rhizobacteria and arbuscular mycorrhizal fungi can be used as biofertilzer to improve soil nitrogen, phosphorus and potassium availability and uptake. Both bacteria and fungi inoculants show potential for use in soil aggregate formation and stabilization and hence,
\end{abstract}

\footnotetext{
E.T. Alori

Department of Crop and Soil Sciences, Landmark University, Omu-Aran, Nigeria

Food Security and Safety Niche Area, Faculty of Agriculture, Science and Technology, 2735 Mmabatho, Mafikeng, South Africa

e-mail: alori.elizabeth@lmu.edu.ng

M.O. Dare

Food Security and Safety Niche Area, Faculty of Agriculture, Science and Technology, 2735 Mmabatho, Mafikeng, South Africa

O.O. Babalola $(*)$

Food Security and Safety Niche Area, Faculty of Agriculture, Science and Technology, 2735 Mmabatho, Mafikeng, South Africa

Food Security and Safety Niche Area, Faculty of Agriculture, Science and Technology, North-West University, 2735 Mmabatho, Mafikeng, South Africa

e-mail: olubukola.babalola@nwu.ac.za
} 
soil structure enhancement. The ability of microbial inoculants to ameliorate plant stress as a result of drought, soil contamination and salinity are also highlighted. The most commonly used microorganisms as biofertilizers, biocontrol and bioremediators include Bacillus spp, Pseudomonas spp, Streptomyces spp Trichoderma spp and Mycorrhizas. Microbial inoculants function through various mechanisms such as production of plant hormones, expansion and elongation of the root system, eliciting induced systemic resistance or systemic acquired resistance, production of lytic enzyme and antibiotic 4-hydroxyphenylactic acid, and production of 1-amino cyclopropane-1-carboxylate-deaminase (ACC-deaminase) in plants rhizosphere. These strategies are safe and sustainable in the long run. The use of appropriate carrier material determines the success of microbial inoculation techniques. Microbial inoculants could either be applied directly to the soil or as seed dressing. The fate of microbial inoculants under field application depends largely on both biotic and abiotic factors. The application of some microbial inoculants could cause a change (which could be a decrease or an increase) in the equilibrium of soil microbial communities while some produce no effect at all.

Keywords Agricultural sustainability $\bullet$ Biocontrol $\bullet$ Biofertilizer $\bullet$ Bioremediation

- Biotechnology $\bullet$ Food security $\bullet$ Microbial inoculants $\bullet$ Plant growth $\bullet$ Plant growth promoting microorganisms (PGPM) • Soil fertility and health

\subsection{Introduction}

The increasing demand for food production with shrinking land resources is a major challenge to agricultural sustainability. Sustainable food production requires efficient use of determinate resources (Owen et al. 2015). Attempt to mitigate the problem include the use of high yielding varieties, chemical fertilizers and pesticides to supplement plant nutrition and control plant pathogens for increased agricultural productivity. However the increasing impacts of these agricultural practices on the environment have gradually affected the quality of soil hence, there is a need to optimize soil productivity in such a way that soil capacity to function as a healthy medium is preserved (Trivedi et al. 2012). The use of eco-friendly resources or input has been a major focus of attention in the past three decades. Although reports on the benefits of using microbial inoculants for plant growth promotion and health in agricultural soil have been inconsistent, there is a promising trend for microbial inoculants to meet the sustainable agricultural production needs. Suggestions to replace or supplement the heavy application of chemical fertilizers with inoculants have been reported (Carvajal-Muñoz and Carmona-Garcia 2012). Microbial inoculants application has been in existence for more than 100 years but gained a lot of prominence in the last three decades with several commercial inoculants products in the market (Babalola and Glick 2012). 

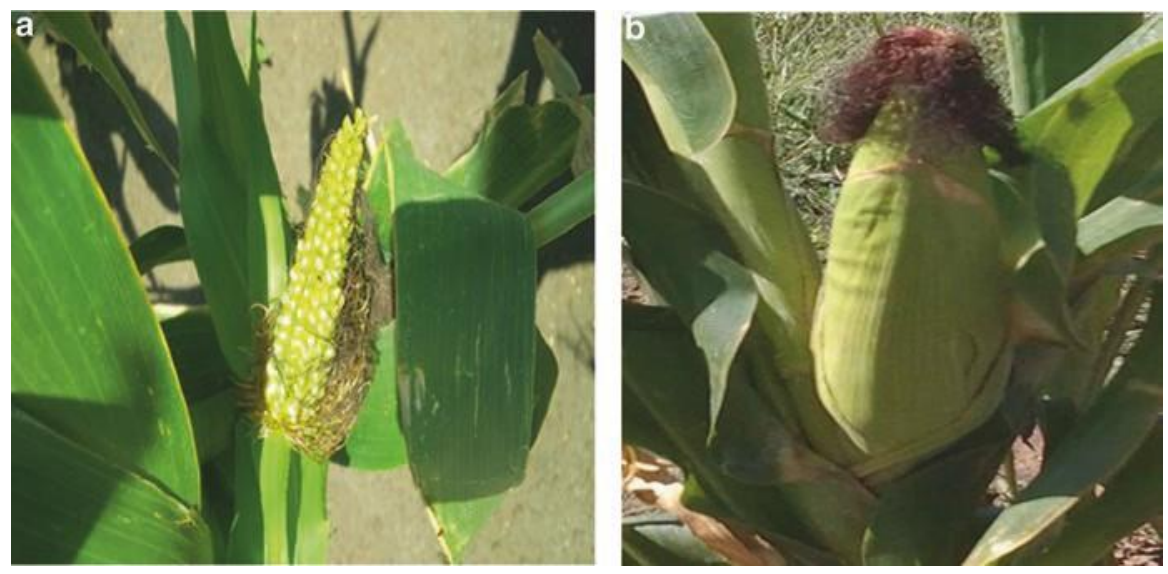

Fig. 9.1 Maize plant (a). Showing Fusarium graminearum infection (b). Inoculated with Pseudomonas sp for biocontrol against Fusarium graminearum

Microbial inoculants participate in many ecosystem biological and chemical processes such as biological control of pathogens (Fig. 9.1) and nutrient cycling, thereby improving nutrient availability. Microbial inoculants application increase biodiversity, creating suitable condition for development of beneficial microorganism. They also improve physical properties of soil such as; improve structure and aggregation of soil particles; reduce soil compaction, increase spore spaces and water infiltration. The antioxidant properties of microbial inoculants promote decomposition of organic matter and increase humus content in soil matrix, and are therefore being considered as an alternative way of reducing the use of chemicals in agriculture (Carvajal-Muñoz and Carmona-Garcia 2012). Microbial inoculants techniques ensure biodegradation of complex substances and develop bioremediation processes in soil contaminated with toxics, xenobiotic and recalcitrant substances.

The strategies involved in plant growth promotion by microbial inoculants could be a direct or indirect mechanism. Directly, inoculation of crop plant with microbial inoculants could result in the expansion and elongation of the root system, leading to improved uptake of water and nutrients (Halpern et al. 2015). Production of growth hormones by microbial inoculants impact root morphogenesis such that plant root hairs and lateral roots are over produced resulting in greater uptake of plant nutrients and hence improvement of plant growth (Kumar et al. 2007). Fixations of atmospheric nitrogen, solubilization of minerals such as phosphorus (P) (Babalola 2010), are also some of the direct mechanisms of influence of microbial inoculants. In indirect growth promotion, Microbial inoculants affect the status of plants by eliciting induced systemic resistance (ISR) or systemic acquired resistance (SAR), by improving disease resistance. These acts prevent soil-borne pathogens from inhibiting plant growth (Yang et al. 2009). Ability to trigger a salicylic acid (SA) -independent pathway controlling systemic resistance is a common trait 
of ISR-inducing biocontrol bacteria. Structural deformities in pathogenic fungi under in vitro culture conditions by the production of diffusible and volatile antifungal compounds have been reported. The bacterial strain successfully restricted the growth of all the test fungi in dual cultures and induced morphological abnormalities such as mycelial and conidial deviations. Also of note is the production of siderophores that solubilize and sequester iron (Hmaeid et al. 2014).

With the increasing use of microbial inoculants for plant growth promotion, this review discusses some of the beneficiary roles of microbial inoculants in plant and soil. It describes changes in soil structure, nutrient solubility as a result of the application of microbial inoculants. We provide an overview of microbial inoculants use for agricultural sustainability, the significance of their application on soil nutrient improvement and soil structure enhancement. Their roles in amelioration of plants stress as a result of drought, soil contaminants, salinity and as biocontrol agents are well explained.

\subsection{Microbial Inoculants}

Microbial inoculation is one of the major agricultural practices that have been used to acquire desirable characteristics in the soil. Microbial inoculants are the formulations of beneficial living microorganisms that when added to soil, improve availability of nutrient to host plant directly or indirectly, thereby promoting plant growth (Gaind 2011). Most of the microorganisms that are used in the production of microbial inoculants inhabit or are capable of inhabiting the soil and perform various roles and functions in the soil. Microbial inoculants in are applied, singly or in combinations, to seeds, plants and soil to enhance their productivity. Different terminologies such as biostimulant (Halpern et al. 2015), bio-inoculants (Singh et al. 2013), and bio-fertilizers (Ansari et al. 2014) have been used to represent these groups of microorganisms. Microbial inoculants include three major groups: (1) plant growth promoting rhizobacteria (PGPR), (2) arbuscular mycorrhiza fungi and (3) the nitrogen-fixing rhizobia, which are usually not considered as PGPR (Yadav and Verma 2014). These groups are known to possess the capacity to enhance nutrient availability, uptake, and support the health of plants to promote plant growth. Microbial inoculants are not nutrients but microorganisms that are able to increase the availability of these nutrients through their biophysical and biochemical activities in soil. Business Communication Co. research report (2011) estimated a compound annual growth rate of about $6.9 \%$ for global microbial inoculants with a market value of $\$ 4.5$ billion in 2010, $\$ 4.9$ billion in 2011 and projected to reach $\$ 6.8$ billion by 2016 (Chatzipavlidis et al. 2013).

Microbial inoculation provides an innovative and cost-effective alternative to overcome salinity stress in soils (Tank and Saraf 2010). The system is environmentally friendly, and poses no health risk to either plant, human or animal. Enhance soil nutrient availability to the plants hence their use as biofertilizers (Ahemad and Kibret 2014). Microbial inoculants provide resistance against pathogens. They can 
Table 9.1 Examples of some microbial inoculants, the test crops and their beneficial properties

\begin{tabular}{|c|c|c|c|}
\hline Microbial inoculants & Test Crop & Beneficial properties & References \\
\hline $\begin{array}{l}\text { Chryseobacterium } \\
\text { indologenes, Pseudomonas } \\
\text { cepacia, P. fluorescens }\end{array}$ & Wide barley & Salt stress & $\begin{array}{l}\text { Hmaeid et al. } \\
(2014)\end{array}$ \\
\hline Bacillus subtilis, $P$. corrugate & Maize & Cool regions $\left(22^{\circ} \mathrm{C}\right)$ & Trivedi et al. (2012) \\
\hline $\begin{array}{l}\text { Paenibacillus yonginensis } \\
\text { DCY84 }\end{array}$ & $\begin{array}{l}\text { Arabidopsis } \\
\text { thaliana }\end{array}$ & Drought, salt stress & $\begin{array}{l}\text { Sukweenadhia et al. } \\
(2015)\end{array}$ \\
\hline Enterobacter sakazakii & Cowpea & Parasitic weed & $\begin{array}{l}\text { Babalola et al. } \\
(2007)\end{array}$ \\
\hline Bacillus subtilis & Cotton & Phytopathogen & $\begin{array}{l}\text { Pereg and McMillan } \\
(2015)\end{array}$ \\
\hline $\begin{array}{l}\text { Scutellospora reticulate, } \\
\text { Glomus pansihalos } \\
\text { (Mycorrhizal fungi) }\end{array}$ & Cowpea & $\begin{array}{l}\text { Soil polluted with } \mathrm{Al} \\
\text { and } \mathrm{Mn}\end{array}$ & $\begin{array}{l}\text { Alori and Fawole } \\
(2012)\end{array}$ \\
\hline Pseudomonas putida & Wheat & Cool region & $\begin{array}{l}\text { Trivedi and Pandey } \\
(2007)\end{array}$ \\
\hline $\begin{array}{l}\text { Trichoderma sp., } \\
\text { Gliocladium sp. }\end{array}$ & $\begin{array}{l}\text { Flowers, } \\
\text { ornamentals }\end{array}$ & Plant pathogens & Julia et al. (2013) \\
\hline $\begin{array}{l}\text { Azotobacter } \mathrm{sp}+ \\
\text { Pseudomonas } \mathrm{sp}\end{array}$ & Mustard & Cadmium & Panwar et al. (2011) \\
\hline Arbuscular mycorrhizal fungi & Citrus & Drought stress & Wu et al. (2013) \\
\hline Burkholderia cepacia & Yellow lupine & Toluene & Barac et al. (2009) \\
\hline $\begin{array}{l}\text { P. fluorescens strains, CHA0 } \\
\text { and Pf1 }\end{array}$ & Banana & Drought stress & Kavino et al. (2010) \\
\hline Gordonia sp. S2Rp-17 & Corn & $\begin{array}{l}\text { Diesel (Soil } \\
\text { contaminant) }\end{array}$ & Hong et al. (2011) \\
\hline Sinorhizobium meliloti & Common reed & Phenanthrene & $\begin{array}{l}\text { Golubev et al. } \\
(2009)\end{array}$ \\
\hline $\begin{array}{l}\text { Bacillus thuringiensis, } \\
\text { Rhizophagus intraradices }\end{array}$ & Trifolium repens & Drought stress & Ortiz et al. (2015) \\
\hline Burkholderia cepacia & Popular & Toluene & $\begin{array}{l}\text { Taghavi et al. } \\
(2005)\end{array}$ \\
\hline Arbuscular mycorrhizal & Olive & Salinity stress & $\begin{array}{l}\text { Porras-Soriano et al. } \\
(2009)\end{array}$ \\
\hline Azospirillum lipoferum & Wheat & Crude oil & $\begin{array}{l}\text { Muratova et al. } \\
(2005)\end{array}$ \\
\hline
\end{tabular}

therefore be used in biological control against plant pathogens (Sukweenadhia et al. 2015) against weed pest (Biological herbicides) (Babalola et al. 2007) and insect pest (Saharan and Nehra 2011). Microbial inoculants can also be used in phytoremediation of polluted soils (Alori and Fawole 2012; Alori 2015). Waterlogged, compacted, desiccated wind and rain eroded soil are remediated through microbial inoculation. Fungal inoculants protect plants against transplant shock, promote environmental resistance to heat and drought (Sukweenadhia et al. 2015) and vastly improve the quality of the soil (Table 9.1). 


\subsubsection{Microbial Inoculants and Soil Fertility Improvement}

\subsubsection{Nitrogen $(\mathbf{N})$}

$\mathrm{N}$ remains the most limiting element for plant growth. The major sources of $\mathrm{N}$ for agricultural soil are mineral fertilizers and biological $\mathrm{N}$ fixation carried out by microorganisms. Nitrogen-fixation is the first step for cycling $\mathrm{N}$ to the biosphere from the atmosphere, a key input of $\mathrm{N}$ for plant productivity (Bernhard 2010). Microbes especially bacteria are important in $\mathrm{N}$ cycling. Bacteria are known to exclusively fix atmospheric $\mathrm{N}$ either symbiotically or asymbiotically due to their possession of the key enzyme nitrogenase which specifically reduces atmospheric $\mathrm{N}$ to ammonia (Wagner 2011).

Symbiotic $\mathrm{N}$ fixation in soil is a process occurring in legume and non-legume plants. The bacteria Rhizobium, Sinorhizobium, Allorhizobium, Bradyrhizobium, Mesorhizobium and Azorhizobium, collectively referred to as rhizobia are responsible for the legume N fixation while Frankia and Actinobacteria are responsible for non-legume $\mathrm{N}$ fixation in soil (Wagner 2011). It is evident that inoculation of legumes with rhizobia has the ability to increase the soil $\mathrm{N}$ status. $\mathrm{N}$ fixed annually by legume-rhizobium association was reported to be about 40-48 million tonnes compared to 98 million year $^{-1}$ of $\mathrm{N}$ fertilizer (Jenkinson 2001). This ability to fix high amounts of $\mathrm{N}$ into the soil is a great potential of rhizobial inoculant to reduce the cost of industrial $\mathrm{N}$ fertilizers, thereby reducing the cost of inputs for farmers. Nitrogen fixation of an effectively nodulated legume is a vital and indispensable aspect of sustainable agriculture. The use of rhizobium inoculant to achieve efficient $\mathrm{N}$ fixation in soil requires the compatibility of the legume and rhizobium inoculant and their adaptability to the environment (Wagner 2011). The few inconsistencies about the ability of the rhizobium inoculant to increase the soil $\mathrm{N}$ are probably due to compatibility and adaptability to the environment issue. Rhizobium must be able to establish, compete and persist with other microflora to form effective nodules in the introduced environment (Gaind 2011). Rhizobial inoculation has played a vital role in legume production in the US and Australia. The legume-cereal cropping system popularized by the International Institute of Tropical Agriculture in sub-Saharan African is also an indication of the growing popularity of the use of rhizobial inoculant. Most crop rotation systems use legume in crop sequence because of the understanding that legumes are able to fix $\mathrm{N}$ and increase the $\mathrm{N}$ status of the soil for the next crop. This has been utilized significantly in soil fertility management for crops to reduce the application of chemical fertilizers. Therefore the proper and efficient use of rhizobial inoculants will ultimately benefit sustainable agricultural production.

A group of bacteria that are free living in the soil commonly referred to as plant growth promoting rhizobacteria/plant growth promoting bacteria/plant growth promoting microorganism have the ability to fix $\mathrm{N}$ into soil (Calvo et al. 2014), when occupying the rhizosphere of crops both legumes and non-legume. These groups of bacteria include the genera of Pseudomonads, Azoarcus, Beijerinckia, Cyanobacteria 
(Nostoc and Anabaena), Klebsiella, Pantoea, Azotobacter, Azospirillum, Bacillus, Burkholderia, Herbaspirillum, and Gluconacebacter diazotrophicus (Egamberdiyeva 2007). Many of these organisms are used as microbial inoculants for crop growth improvement, singly or in combination with other organisms. Unlike rhizobial inoculants, the use of many of these bacteria as a single inoculant to increase soil $\mathrm{N}$ fertility for crop use has not been very effective. Although they may not be as effective as rhizobium, there is potential for improvement in their ability to help in sustainable agricultural production. Although the ability of many plant growth promoting rhizobacterial to increase $\mathrm{N}$ content of the soil are very inconsistent, some cases of appreciable soil $\mathrm{N}$ increase have been observed especially when the inoculants contain more than one of the organisms. The use of Azospirillum as helper bacteria used in combination with rhizobium increased the effect of rhizobium in soil fixation. Azotobacter and rhizobium contributed $78.8 \mathrm{~kg}$ $\mathrm{N} \mathrm{ha}^{-1}$ year $^{-1}$ total $\mathrm{N}$ to soil in soybean-wheat rotation (Rawat et al. 2013).

Plant nutrition for $\mathrm{N}$ has also been improved by the application of some fungal inoculants. Arbuscular mycorrhizal fungi that form associations with more than 80 $\%$ of plants including most crops have also been identified as a probable $\mathrm{N}$ mobilizer for plants (Hodge and Storer 2015; Veresoglou et al. 2012). However, the contribution of arbuscular mycorrhizal fungi to plant $\mathrm{N}$ uptake varies widely and the reasons for the variability are still unclear and may likely be resolved by the application of genomics and metabolomics technology (Hodge and Storer 2015). The role of arbuscular mycorrhizal fungi in plant $\mathrm{P}$ nutrition and soil structure improvement is well established, and the prospect of involving it in the $\mathrm{N}$ nutrition of crops will be a giant stride in tackling soil degradation problems through the use of microbial inoculants. Microbial inoculants such as rhizobium, plant growth promoting rhizobacteria and arbuscular mycorrhizal fungi have the potential to be used as biofertilizer to improve soil $\mathrm{N}$ availability and supply for sustainable agriculture

\subsubsection{Phosphorus}

Phosphorus is an essential macronutrient required by plants for their growth and development. It makes up about $0.1 \%$ of the earths' crust (Sanderson 2014). However, most of the $\mathrm{P}$ in the earth's crust is in insoluble form and not readily available to plants. Low soil available $\mathrm{P}$ limits about $40 \%$ of crop production in arable land worldwide (Bargaz et al. 2012). To compound the problem of P availability, added $\mathrm{P}$ fertilizers undergo fixation due to the complex exchanges within the soil limiting the availability of P to plants (Zhu et al. 2011).

The role of microbial inoculants in increasing the availability of soil $\mathrm{P}$ for plant growth can be viewed from two perspectives: firstly the solubilization of $\mathrm{P}$ from the mineral rock thereby increasing the available $\mathrm{P}$ in soil solution and secondly the mobilization of the available $\mathrm{P}$ to the plant roots for uptake. Phosphate solubilizing microorganisms and phosphate mobilizing microorganisms (Owen et al. 2015) include the genera of some bacteria and fungi that have been identified to solubilize and render insoluble soil $\mathrm{P}$ available to plants with their production of organic acids 
and enzyme phosphatases and phytase (Calvo et al. 2014). These organisms include Pseudomonas, Azospirillum, Azotobacter, Bacillus, Burkholderia, Enterobacter, Rhizobium, Erwinia, Streptomyces, Achromobacter Flavobacterium and mycorrhiza (Ma et al. 2009). These microorganisms produce organic acids that chelate the cations bound to phosphate and convert them to soluble form (Calvo et al. 2014). They also produce the enzymes phytases and phosphatases that dephosphorylate phytates, the predominant organic $\mathrm{P}$ in the soil (60\% of organic $\mathrm{P}$ ) to release $\mathrm{P}$ in a form available to plants (Singh and Satyanarayana 2011).The application of these organisms, either as bacterial or fungal inoculants, has advantage over the P fertilizers that readily form complexes in the soil when applied because the microbes can continuously supply available $\mathrm{P}$ to plants over a long range of time. Soil management practices that incorporate microbial inoculant application can really benefit from the sustained $\mathrm{P}$ supply to crops.

Fungal inoculants that have P solubilizing/mobilizing potential are well known. The most studied among the P mobilizing fungi is the arbuscular mycorrhizal fungi. Arbuscular mycorrhizal fungi are widespread in the plant kingdom and contribute significantly to plant $\mathrm{P}$ nutrition and growth in natural ecosystems (Smith et al. 2011). The mechanism of increased $P$ uptake by Arbuscular mycorrhizal fungi has been attributed to the fungal extra radical hyphae growing beyond the phosphate depletion zone that develops around the root (Smith and Read 2008). Positive effects of arbuscular mycorrhizal fungi inoculation on the growth and $\mathrm{P}$ nutrition of crops have been reported (Cozzolino et al. 2013; Dare et al. 2010). Many mycorrhizal inoculants have been produced on a commercial scale, mostly in the US and Europe. Rhizophagus (formerly Glomus) intraradices and Funneliformis (formerly Glomus) mosseae (Kruger et al. 2012) are some of the common mycorrhizal inoculants which have been shown to increase P uptake in diverse crop plants (Dare et al. 2010; Cozzolino et al. 2013). Some other fungi such as Aspergillus and Penicillium species are able to solubilise inorganic phosphate and mineralise organic phosphate by secreting organic acids and producing phosphatase enzymes (Wang et al. 2015). The significant role of microbial inoculants in increasing the sustainable availability of $\mathrm{P}$ to plant is that of $\mathrm{P}$ solubilization and $\mathrm{P}$ mobilization.

\subsubsection{Potassium $(\mathrm{K})$}

Potassium is one of the most important macronutrient for plant growth and the third in fertilizer formulation after $\mathrm{N}$ and $\mathrm{P}$. Potassium is one of the seven most common elements in the earth's crust and makes up $2.6 \%$ of the earth's surface layer (Meena et al. 2014). Inadequate supplies of K to plants can lead to poor root growth, slow growth and lower yields in crops (White and Karley 2010).

K-solubilizing microorganisms present in soil and plant rhizosphere are evidently involved in the K cycles (Liu et al. 2012). Potassium-solubilizing microorganisms improve soil nutrients and structure and plant growth by releasing $\mathrm{K}$ from insoluble minerals into the soil (Meena et al. 2014). The microorganisms in the 
soil or rhizosphere solubilize mineral $\mathrm{K}$ by synthesizing organic acids (Parmar and Sindhu 2013). A wide range of rhizospheric microorganisms that have been used as inoculants for increasing the $\mathrm{K}$ soil content or $\mathrm{K}$ plant nutrition include Acidithiobacillus ferrooxidans, Arthrobacter sp.Bacillus edaphicus, Bacillus circulans, Bacillus mucilaginosus, Burkholderia sp., and Paenibacillus sp.(Zarjani et al. 2013; Sangeeth et al. 2012) These organisms convert insoluble or mineral structural $\mathrm{K}$ compounds into soluble form and make them available for plants.

AM fungal inoculants have also been reported to increase $\mathrm{K}$ uptake. Arbuscular mycorrhizal releases proton $\mathrm{H}^{+}$or $\mathrm{CO}_{2}$ and organic anions such as citrate malate and oxalate which increase the solubility of mineral K (Meena et al. 2014). However, the increased $\mathrm{K}$ by mycorrhizal has often been linked to increased $\mathrm{P}$ availability (Cardoso and Kuyper 2006). Plant growth promoting rhizobacteria and Arbuscular mycorrhizal fungi are responsible for K solubilization and mobilization for sustainable improvement of $\mathrm{K}$ availability to plants.

\subsubsection{Potentials of Microbial Inoculants in Soil Structure Enhancement}

Soil structure is a crucial aspect of sustainability in agriculture and ecosystem functioning because of its influence on the biological, physical and chemical properties of the soil. It refers to the three dimensional arrangement of organic or mineral complexes (aggregates) and pore spaces, which is usually quantified by size distribution of aggregate or the stability of aggregates. Aggregate formation and stabilization are mediated by several factors which include soil microorganisms (Lucas et al. 2013).

The role of microorganisms in the aggregate formation and stabilization of soil is well documented (Lucas et al. 2013; Helliwell et al. 2014). Activities of bacteria and fungi applied as inoculants in the enhancement of soil structure are affected by the aggregate scale (micro- or macroaggregate), soil types and soil mineralogy (Six et al. 2004). Aggregates are divided into microaggregate $(<250 \mu \mathrm{m})$ and macroaggregate $(>250 \mu \mathrm{m})$ and this division influences bacteria and fungi differently. While fungi stabilize macroaggregates, bacteria are more involved in the enhancement of microaggregates (Bossuyt et al. 2001). Bacteria play less role in coarse textured sandy soil where only the hyphal network is able to cross-link the abundant sand particles to form stable aggregates, whereas in clayey soil, both bacteria and fungi and their product play the role in aggregation (Six et al. 2004). Fungi are unique in influencing soil aggregate formation and stabilization because of the hyphae development and production of extra cellular polysaccharides. Hyphal networks enmesh and entangle macroaggregates while extracellular polysaccharides help to bind the micro-aggregates into stable macroaggregates (Bossuyt et al. 2001). Bacterial inoculants could play a key role in the soil structural stabilization through their secretions and exudates for microaggregate formation and stabilization. 
The most studied fungi in soil structure stabilization are mycorrhizal fungi. Mycorrhizas are well recognized for their role in the improvement of soil structure (Leifheit et al. 2014). According to Rillig and Mummey (2006), mycorrhiza can influence soil aggregation at three main different scales; plant community, individual host plant root and fungal mycelium. Mycorrhizal ability to affect the plant community composition and cause root morphological changes to individual plants is well established (Oláh et al. 2005). However, our focus in this review is on the fungal mycelium which develops with the application of the fungal inoculant. Arbuscular mycorrhiza contribute to soil structure by 1) developing extraradical hyphae into the soil that align soil particles, providing the skeletal structure that enmeshes microaggregates to form macroaggregates; 2) secreting product like glomalin and glomalin related protein, mucilage, polysaccharides, hydrophobins and other extracellular compounds that cement aggregates and 3) delivering plantderived carbon to aggregate surfaces (Rillig and Mummey 2006; Cardoso and Kuyper 2006). These processes are important for soil aggregation because of the space occupied by arbuscular mycorrhizal fungi in the soil system. Arbuscular mycorrhizal fungi produce significant biomass and represent dominant fungal biomass in agricultural soil (Rillig and Mummey 2006) and this is probably the reason for the positive effect of arbuscular mycorrhizal fungi inoculation on soil aggregation as reported by Leifheit et al. (2014). Considering the agricultural practices that are damaging to the soil structure, the use of mycorrhizal inoculants will not only help in the nutrition of crops, but also enhance the structural stability of agricultural soil. Both bacteria and fungi inoculants show potential for use in sustainable soil aggregate formation and stabilization and hence, soil structure enhancement.

\subsubsection{Role of Microbial Inoculants in Crop Tolerance to Drought Stress}

By reason of global climate change, drought is becoming more frequent and extreme in most part of the world. In most ecosystems, both fungi and bacteria are capable of resisting drought condition. However fungi show greater resistance than bacteria. Yuste et al. (2011), reported that fungi persisted longer in forest and desert soils during drought than bacteria. Arbuscular mycorrhizal fungi and saprophytic fungi have also exhibited better resistance to a wider range of heat and drought conditions compared to bacteria, However actinomycetes was an exception (Bell et al. 2009). This is not far from the fact fungi have extensive hyphal networks that enable them to access a larger volume of soil. These help fungi to regulate osmotic stress more effectively than bacteria (Leifheit et al. 2014). In the same vein Arbuscular mycorrhizal fungi show greater tolerance to drought than the saprophytic group (Davinic et al. 2013). This is associated with its ability to enhance greater plant nutrient and water uptake, greater carbon assimilation efficiencies. Fungi are also able to breakdown more complex organic structures such as cellulose and lignin (Schwarze et al. 2004). 
The discovery of some soil microorganism associated with natural drought condition in different ecological conditions, has necessitate their use as inoculants in drought season. The mechanisms by wish these inoculants enhance plant drought tolerance include: increased hydric content, decreased antioxidant enzymatic activities, increased nutrient uptake, and decreased stomata conductance. They are also able to maintain indole acetic acid and increase proline production. Arbuscular mycorrhizal inoculants can improve crop drought tolerance in crop via glomalin induced changes in soil structure. Microbial inoculation during drought increased; plant growth, physiological and biochemical plant values that aid adaptive plant response, root growths, water content and plant $\mathrm{C}, \mathrm{K}, \mathrm{Ca}$ and $\mathrm{Mg}$ content (Armada et al. 2014). Some microorganisms that have been used to improve crop tolerance to drought include: Arbuscular mycorrhizal fungi such as Glomus intraradices, Glomus mosseae, Aspergillus niger, Phanerochaete chrysosporium (Medina et al. 2010; Wu et al. 2013), Bacillus megaterium (Armada et al. 2014). Burkholderia phytofirmans PsJN, Enterobacter sp. FD17 (Naveed et al. 2014), Pseudomonas putida (Armada et al. 2014), Azospirillum sp (Moutia et al. 2010), Bacillus thuringiens, Rhizophagus intraradices (Ortiz et al. 2015).

\subsubsection{Microbial Inoculants in the Remediation of Contaminated Soil}

Bioaugmentation of tolerant crops with microbial inoculants can enhance plant establishment and growth under stress conditions including in the presence of soil contaminants. Phytoremediation of contaminated soil assisted by microbial inoculants enhance plant growth through: Production of plant growth hormones such as indole acetic acid and cytokinins, essential nutrients released by nitrogen fixers' siderophore producers and phosphorus solubilizer and suppression of the production of stress producing ethylene and hence have the potential to aid phytoremediation. Microbial inoculants are capable of remediating both organic and inorganic soil contaminants (Alori 2015). Some plants and associated microbial inoculants in phytoremediation of some soil inoculants are shown in Table 9.2.

Plants, in association with microbial inoculant, can remove or transform contaminants into harmless substance. Microbial populations through the release of chelating gents, acidification, phosphate solubilization and redox changes, affect heavy metal mobility and availability to the plant. The use of microbial inoculants in phytoremediation of polluted soil is cost efficient than alternative engineeringbased solutions such as incineration, soil excavation, or land filling of the contaminated materials. Site use and remediation can occur simultaneously. It is an in situ approach, It treats the contamination in place so that large quantities of soil, sediment or water do not have to be pumped out or dug up of the ground for treatment. It is environmentally friendly, i.e, poses no health risk to neither plant, human nor animal. It enhances soil nutrient availability to the plants. Require less equipment 
Table 9.2 Some microbial inoculants in phytoremediation of contaminated soil

\begin{tabular}{|c|c|c|c|}
\hline Remediator (plant) & Microbial inoculants & Contaminant & References \\
\hline $\begin{array}{l}\text { Withania } \\
\text { somnifera }\end{array}$ & $\begin{array}{l}\text { Staphylococcus cohnni } \\
\text { subsp urealyticus }\end{array}$ & Lindane & $\begin{array}{l}\text { Abhilash et al. } \\
\text { (2011) }\end{array}$ \\
\hline $\begin{array}{l}\text { Lolium sp and } \\
\text { Medicago sativa }\end{array}$ & Enterobacter ludwigii & Hydrocarbon & $\begin{array}{l}\text { Yousaf et al. } \\
\text { (2011) }\end{array}$ \\
\hline Cytisus striatus & Rhodococcus erythropoli & Hexachlorocyclohexane & $\begin{array}{l}\text { Becerra-Castro } \\
\text { et al. (2013) }\end{array}$ \\
\hline Brassica juncea & $\begin{array}{l}\text { Azotobacter } \mathrm{sp}+ \\
\text { Pseudomonas } \mathrm{sp}\end{array}$ & Cadmium & $\begin{array}{l}\text { Panwar et al. } \\
(2011)\end{array}$ \\
\hline $\begin{array}{l}\text { Arabidopsis } \\
\text { thaliana }\end{array}$ & $\begin{array}{l}\text { Achromobacter } \\
\text { xylosoxidans } \mathrm{F} 3 \mathrm{~B}\end{array}$ & Aromatic compounds & Ho et al. (2012) \\
\hline $\begin{array}{l}\text { Lolium } \\
\text { multiflorum }\end{array}$ & $\begin{array}{l}\text { Pseudomonas sp. ITRH76, } \\
\text { Rhodococcus } \text { sp. ITRH } 43\end{array}$ & Diesel & $\begin{array}{l}\text { Afzal et al. (2011, } \\
\text { 2012) }\end{array}$ \\
\hline $\begin{array}{l}\text { Phragmites } \\
\text { australis }\end{array}$ & Pseudomonas asplenii AC & Copper, and creosote & Reed et al. (2005) \\
\hline Brassica juncea & $\begin{array}{l}\text { Bacillus argabhattai and } \\
\text { Bacillus megaterium }\end{array}$ & Cadmium & $\begin{array}{l}\text { Jeong et al. } \\
(2013)\end{array}$ \\
\hline $\begin{array}{l}\text { Lolium } \\
\text { multiflorum }\end{array}$ & $\begin{array}{l}\text { Pseudomonas putida } \\
\text { PCL1444 }\end{array}$ & Naphthalene & $\begin{array}{l}\text { Kuiper et al. } \\
\text { (2004) }\end{array}$ \\
\hline $\begin{array}{l}\text { Arabidopsis } \\
\text { thaliana }\end{array}$ & Paenibacillus yonginensis & Aluminium & $\begin{array}{l}\text { Sukweenadhi } \\
\text { et al. (2015) }\end{array}$ \\
\hline $\begin{array}{l}\text { Lolium } \\
\text { multiflorum }\end{array}$ & $\begin{array}{l}\text { Pseudomonas } \\
\text { nitroreducens PS-2 }\end{array}$ & Chlorpyrifos & $\begin{array}{l}\text { Korade and } \\
\text { Fulekar (2009) }\end{array}$ \\
\hline $\begin{array}{l}\text { Phragmites } \\
\text { australis }\end{array}$ & $\begin{array}{l}\text { Sinorhizobium meliloti } \\
\text { P221 }\end{array}$ & Phenanthrene & $\begin{array}{l}\text { Golubev et al. } \\
(2009)\end{array}$ \\
\hline Triticum aestivum & Azospirillum lipoferum & Crude oil & $\begin{array}{l}\text { Muratova et al. } \\
(2005)\end{array}$ \\
\hline Vigna mungo & $\begin{array}{l}\text { Pseudomonas aeruginosa } \\
\text { MKRh3 }\end{array}$ & Cadmium & Ganesan (2008) \\
\hline Pisum sativum & $\begin{array}{l}\text { Pseudomonas putida } \\
\text { VM1441 (pNAH7) }\end{array}$ & Naphthalene & $\begin{array}{l}\text { Germaine et al. } \\
(2009)\end{array}$ \\
\hline $\begin{array}{l}\text { Phragmites } \\
\text { australis }\end{array}$ & $\begin{array}{l}\text { Autochthonous } \\
\text { microorganism consortium }\end{array}$ & Copper & $\begin{array}{l}\text { Oliveira et al. } \\
\text { (2014) }\end{array}$ \\
\hline $\begin{array}{l}\text { Juncus maritimus } \\
\text { and Phragmites } \\
\text { australis }\end{array}$ & $\begin{array}{l}\text { Autochthonous } \\
\text { microorganism consortium }\end{array}$ & Cadmium & $\begin{array}{l}\text { Teixeira et al. } \\
(2014)\end{array}$ \\
\hline
\end{tabular}

and labour than other methods, Phytoremediation using microbial inoculants does not degrade the physical or chemical health of the soil, unlike the soil excavation method that removes the topsoil that is rich in organic-matter- and the heavy machinery used compact the soil that is left behind. Microbial assisted phytoremediation do not require digging up or hauling of soil, hence it saves energy (Alori 2015). The strategies of microbial inoculants in remediation of polluted soil are safe and the effects are sustainable. 


\subsubsection{Benefits of Microbial Inoculation in Saline Soil}

Salination of agricultural soil has become a serious threat to food production and security. According to (Shirmadi et al. 2010) about $5 \%$ of the world soil is currently affected salinity. Vinocur and Altman (2005), predicted that by the year 2050, about $50 \%$ of agricultural soils will be affected by salinity increase. Salinity has a direct effect on both the physical-chemical and biological properties of the soil, rendering such soils unsuitable for crop growth and biological processes. High soil salinity results in disruption in the uptake and transformation of nutrient elements such as $\mathrm{Mg}^{2+}$ and $\mathrm{Ca}^{2+}$ by plant. More also, it reduces ion activity in soil solution thereby, leading to nutrient deficiency and reduction of overall growth and yield quality of plant.Paul and Nair (2008), stress that plants become vulnerable to soil borne diseases under saline stress In the past, some of the strategies employed to alleviate salt stress include the following: leaching of excess soluble salts from upper to lower soil depth, developing salt resistant cultivars, harvesting salt accumulating aerial plant parts in areas with negligible irrigation (Karthikeyan et al. 2012). These strategies are labour intensive and highly scientific. As a result, cost of cultivation may become increased and sometimes impossible. This has necessitated the need to discover agronomic system that can support plant growth under salinity stress that will not be accompanied by any environmental or health hazard.

Some soil microorganisms have been identified to be capable of alleviating salinity stress in plants and thus improving plants growth and yield. These soil microorganisms include the following genera: Agrobacteria, Azospirillum, Bacillus, Glomus Gordonia and Pseudomonas. They are environmentally-friendly, economically viable and energy efficient. The application of these groups of microorganisms is therefore a promising approach for alleviating salinity stress in plants.

Microbial inoculants ameliorate salt stress in plant via increased nutrient uptake, induced antioxidative defense system, modulation of the level of plant hormones, and reduction of ethylene level by producing 1-aminocyclopropane-1-carboxylatedeaminase in plants rhizosphere. Inoculation of sunflower with Pseudomonas fluorescens biotype $\mathrm{F}$ and Pseudomonas fluorescens $\mathrm{CECT} 378^{\mathrm{T}}$ in sun flower grown in substrate with addition of salt $(\mathrm{NaCl})$ showed that these strains that alleviate salt stress in sun flower produced indole-3-acetic acid and siderophores. The crop plants inoculated had a better developed root and a better $\mathrm{K}^{+}: \mathrm{Na}^{+}$ratio in the shoot (Shilev et al. 2012). In the same vein, Jha et al. (2011) discovered that the inoculation of a local paddy rice with Pseudomonas pseudoacaligenes and Bacillus pumilus in saline soil resulted in a decrease in growth suppression evident by an increased dry weight. The microbial inoculants also induced some osmoprotectants which help to overcome the deleterious effects of salt stress. 


\subsubsection{Benefits of Microbial Inoculations as Biofertilizer on Plants Growth}

Some reports in literature collated recently by Babalola and Glick (2012) describe microbial inoculation to improve plant fitness and plant yield components. Microbial inoculation improves most plants growth and vigor. They enhance root growth and exudation (Babalola 2010; Trabelsi and Mhamdi 2013). When applied seeds, plants surface or soil, microbial inoculants increase the availability and supply of essential nutrients to host plants and thereby promoting growth. Microbial-inoculated plants show a reduction in membrane potential, accelerated osmotic adjustment, and enhanced lateral root development due to higher nitric acid and indole-3-acetic acid production (Dimkpa et al. 2009). Fungal inoculants will harmonize with the plant's root system and greatly expand the surface area of the root mass. Production of phytohormones by microbial inoculants can result in modification of root morphogenesis and hence support water uptake to plant roots.

Some common microbial components of biofertilizers include: Azotobacter, Azospirillum, Bradyrhizobium, mycorrhizae, phosphorus solubilizing bacteria, and Rhizobium. Microbial biofertilizers could be grouped into; Nitrogen fixers e.g. Rhizobium and Bradyrhizobium, phosphate solubilizers e.g. Pseudomonas, bacillus, Aspergillus etc., cellulose degraders such as Cytophaga and phosphate mobilizers such as mycorrhizae. Microbial bio-fertilizers are cost effective and cheaper than the conventional techniques. They provide 25-30\% of chemical fertilizer equivalent of nitrogen. They increase phosphorus and potassium, increase water absorption and keep soil biologically active. In soils cropped with legumes, the application of arbuscular mycorrhizal fungi inoculants tremendously improve growth and yields. More also, inoculation with arbuscular mycorrhizal fungi improved growth of chickpea (Cicer arietinum L.) and doubled P uptake at low and intermediate levels of $\mathrm{P}$ in a pot experiment on sterilized low-P calcareous soil (Mohammadi et al. 2011). The inoculation of maize with Trichoderma harzianum strain T22 as a biofertilizer shortens the plant growth period and time and reduced lignifications hence, enhanced fresh state of maize plant (Akladious and Abbas 2012). An improved grain yield was reported by (N'Cho et al. 2013) when soybean was co-inoculated with rhizobium and fungal inoculants and application of foliar fertilizer.

However, microbial biofertilizers are associated with the following limitations:

(i) The performance and efficacy of microbial inoculants (Biofertilizers) cannot be easily tested in the field i.e. there is a block in biofertilizer development.

(ii) The efficacy of biofertilizers is not reliable. The mechanism of action of the biofertilizers in promoting growth is not yet well understood. In attempting to deal with these issues, research into biofertilizer is increasing.

(iii) The essential nutrient may not be available in sufficient quantities to plants. Nutritional deficiency could exist due to low transfer of micro and macro nutrients 


\subsubsection{Benefits of Microbial Inoculants as Biocontrol Agents}

Microbial inoculants have offered eco-friendly control mechanism against plant pathogens. Microbial inoculants produce antifungal secondary metabolites such as 2, 4-diacetylphloroglucinol and lytic enzymes. Some also confer plant protection against the activities of dieses causing organism by producing chitinase and protease enzymes. Microbial biocontrol agents also antagonize pathogens by competitive colonization of plant root and by forming biofilms in the hydroponic and soil systems.

Numerous microbial inoculants for control of several diseases especially species of the bacteria Pseudomonas, Bacillus, Enterobacter, Streptomyces and the fungus Trichoderma-, causing plant diseases as leaf spots, brown patch, Pythium blight and root rot, Fusarium wilt, dollar spot, summer patch, take-all patch, Verticillium wilt and Typhula blight have been studied by various researchers. Table 9.3 shows some microorganisms that had exhibited some biocontrol activity against some phytopathogens.

Table 9.3 Microbial inoculants used as biocontrol agents

\begin{tabular}{|c|c|c|c|}
\hline Biocontrol agents & Plant disease/Pathogen & Crop & References \\
\hline Bacillus subtilis HJ5 & Verticillium wilt & Cotton & Li et al. (2013) \\
\hline Bacillus subtilis SQR9 & Fusarium wilt & Cucumber & Cao et al. (2011) \\
\hline Bacillus subtilis & Fusarium wilt & Maize & $\begin{array}{l}\text { Cavaglieri et al. } \\
(2005)\end{array}$ \\
\hline Trichoderma asperellum T-34 & Rhizoctonia solani & Cucumber & Trillas et al. (2006) \\
\hline $\begin{array}{l}\text { Trichoderma harzianum } \\
\text { SQR-T } 037\end{array}$ & Fusarium wilt & Cucumber & Yang et al. (2011) \\
\hline $\begin{array}{l}\text { Paenibacillus polymyxa, } \\
\text { Trichoderma harzianum }\end{array}$ & Fusarium wilt & $\begin{array}{l}\text { Water } \\
\text { melon }\end{array}$ & Wu et al. (2009) \\
\hline Streptomyces sp strain g10 & Fusarium wilt & Banana & Getha et al. (2005) \\
\hline Pseudomonas spp & Verticillium wilt & Cotton & \begin{tabular}{|l} 
Erdogan and \\
Benlioglu (2010) \\
\end{tabular} \\
\hline Bacillus pumilus SQR-N43 & Rhizoctonia solani & Cucumber & Huang et al. (2012) \\
\hline $\begin{array}{l}\text { Streptomyces mutabilis NBRC } \\
12800\end{array}$ & $\begin{array}{l}\text { Rhizoctonia solani } \\
\text { damping-off }\end{array}$ & Tomato & Goudjal et al. (2014) \\
\hline Bacillus amyloliquefaciens & Panama disease & Banana & Xue et al. (2015) \\
\hline Streptomyces & Phytophthora root rots & Alfalfa & Xiao et al. (2002) \\
\hline Streptomyces & Damping-off & Sugar beet & Sadeghi et al. (2006) \\
\hline $\begin{array}{l}\text { Actinoplanes campanulatus, } \\
\text { Micromonospora chalcea and } \\
\text { Streptomyces spiralis }\end{array}$ & $\begin{array}{l}\text { Pythium } \\
\text { aphanidermatum }\end{array}$ & Cucumber & $\begin{array}{l}\text { El-Tarabily et al. } \\
\text { (2008) }\end{array}$ \\
\hline Streptomyces & Sclerotium rolfsii & Sugar beet & Errakhi et al. (2007) \\
\hline Streptomyces & Damping off & Tomato & $\begin{array}{l}\text { Dhanasekaran et al. } \\
(2005)\end{array}$ \\
\hline $\begin{array}{l}\text { Micromonospora aurantiaca, } \\
\text { Streptomyces griseus }\end{array}$ & Damping off & Wheat & Hamdali et al. (2008) \\
\hline $\begin{array}{l}\text { Bacillus pumilus, Pseudomonas } \\
\text { alcaligenes, and Rhizobium sp. }\end{array}$ & Wilt disease & Lentil & Akhtar et al. (2010) \\
\hline Bacillus subtilis & Stem-end rot & $\begin{array}{l}\text { Avocado } \\
\text { flowers }\end{array}$ & $\begin{array}{l}\text { Demoz and Korsten } \\
\text { (2006) }\end{array}$ \\
\hline
\end{tabular}




\subsection{Characteristics of Good Inoculants}

Most microbial inoculants have received attention because of their catabolic versatility (Hmaeid et al. 2014), excellent root-colonizing ability which includes; motility, adhesion and growth rate (Hmaeid et al. 2014). They have capacity to produce a wide range of enzymes and metabolites, the ability to produce auxin or indole acetic acid, solubilize phosphate, produce siderophores (Hmaeid et al. 2014), survive and multiply in microhabitats associated with the root surface, in competition with other microbiota (Nivedhitha et al. 2008). They can persist in soil, are stable in storage and culture and are able to tolerate environmental constrains such as stress caused by fluctuating soil water conditions, use of fertilizers or agrochemicals (both organic and conventional) and soil disturbance such as cultivation (Hungaria et al. 2005). The success of microbial inoculation depends largely on the following: the plant species and cultivar, soil type, soil moisture and temperature conditions, the number of pathogens present in the soil around the plant and how the inoculants were prepared and applied (Babalola et al. 2007).

\subsection{Properties of Good Carriers for Microbial Inoculants}

The use of appropriate carriers for microbial inoculants preparation cannot be over emphasized. Good microbial inoculants carrier should (i) be easily handled and stored for a long period of time. (ii) have the capacity to deliver the right number of viable microbial cells in appropriate physiological condition at the right time, (iii) protect microbial cells from various biotic and abiotic stresses they will face once applied to the soil, (iv) retain microbial Plant-Growth Promoting abilities after a long period of storage, (v) be of low cost and locally available, (vi) be mixable and package able, (vii) permit gas exchange, particularly oxygen and have high organic matter content and water holding and retention capacity and it should be more than $50 \%$, (viii) be easy to process (mixing, curing and packaging operations) and free of lump- forming materials, (ix) be easy to sterilize by autoclaving or gammairradiation, (x) have good adhesion of seeds (xi) have good $\mathrm{pH}$ buffering capacity and (xii) be nontoxic to plants (Ferreira and Castro 2005).

Bacterial inoculants should be kept under a cool temperature, between $1.1{ }^{\circ} \mathrm{C}$ and $21.1{ }^{\circ} \mathrm{C}$ is best, away from extreme heat, direct sunlight or exposure to the elements or repeated freezing and thawing. Fungal inoculants are best kept dry. Excessive heat or cold is never of benefit. Also to be noted is the fact that agronomic practices have profound effects on soil organisms. They should therefore be designed to work in harmony with microbial inoculants and biological processes in order to support sustainable agricultural systems. Table 9.4 shows some materials that have successfully been used as carrier for microbial inoculants and the associated microbes. The use of appropriate carrier material determines the success of microbial inoculation techniques 
Table 9.4 Types of carriers used for inoculants production

\begin{tabular}{l|l|l}
\hline Carrier material & Inoculants & References \\
\hline $\begin{array}{l}\text { Sterilized oxalic acid, sludge, industrial waste, } \\
\text { alginate-perlite dry granules, soybean oil or } \\
\text { peanut oil added with lyophilized cells, } \\
\text { composted sawdust, nutrient supplemented } \\
\text { pumice, mineral soils, diatom, porosil mp, } \\
\text { microcel, vermiculite, agriperlite, expanded } \\
\text { clay, kaolin, celite, wheat bran, sugarcane } \\
\text { bagasse, coal/charcoal, granular inoculants } \\
\text { amended with nutrient and perlite }\end{array}$ & $\begin{array}{l}\text { Rhizobium, Sinorhizobium, } \\
\text { Agrobacterium, Phosphorus } \\
\text { solubilizing fungi, and } \\
\text { Aspergillus niger, }\end{array}$ & $\begin{array}{l}\text { Zaidi et al. } \\
(2014)\end{array}$ \\
\hline $\begin{array}{l}\text { Alginate beads supplemented with skim milk, } \\
\text { charcoal based, broth based }\end{array}$ & $\begin{array}{l}\text { Bacillus subtilis, } \\
\text { Pseudomonas corrugate }\end{array}$ & $\begin{array}{l}\text { Trivedi et al. } \\
(2012)\end{array}$ \\
\hline $\begin{array}{l}\text { Talc powder +carboxyl- methyl cellulose } \\
\text { Pseudomonas fluorescence }\end{array}$ & $\begin{array}{l}\text { Negi et al. } \\
(2005)\end{array}$ \\
\hline
\end{tabular}

\subsection{Methods of Application of Microbial Inoculants}

The soil environmental conditions for crop production can be optimized by introducing friendly environmental microbial formulations to the soil. The use of appropriate carriers for microbial inoculants preparation is critical for the success of microbial inoculation (Babalola 2010). Microbial inoculant formulations are sold as wet able powders, granules or liquids sprays (Babalola and Glick 2012). The following methods can be used (Table 9.5). Microbial inoculants could be made of a singular strain of microbe. This approach is called the monoculture approach, where as an inoculant made of two or more strain of microbe or different types of organism is referred to as a co- culture or multiple culture approach. Microbial inoculants could either be applied directly to the soil or as seed/seedling dressing.

\subsection{Factors that Determine the Performance of Microbial Inoculants Under Field Condition}

The fate of introduced microbial inoculants includes: the ability to survive inoculation on seed, multiply in the spermosphere in response to seed exudates, attach to the root surface and colonize the developing root system. The ability of microbial inoculants to compete with indigenous microorganism present in the rhizosphere and the soil, for successful colonization of a developing plant depends on a number of biotic and abiotic factors. The survival, colonization and establishment of the inoculated microbes depend largely on these factors.

For microbial inoculants to survive competition, they must be able to sense chemo attractants like lipopolysaccharide such as O-antigen chain. However, lipopolysaccharide in colonization is strain dependent. O-antigenic side chain of Pseudomonas fluorescens PCL1205 is involve in tomato root colonization whereas 
Table 9.5 Methods of application of microbial inoculants

\begin{tabular}{|c|c|c|c|}
\hline Methods & Mechanism of application & Advantages and limitation & References \\
\hline $\begin{array}{l}\text { Directly to } \\
\text { the soil }\end{array}$ & $\begin{array}{l}\text { After seed germination, } \\
\text { they are applied directly to } \\
\text { the soil at the plant base } \\
\text { near the plant roots }\end{array}$ & $\begin{array}{l}\text { Withstand low moisture } \\
\text { conditions better than carrier } \\
\text { based inoculants. A less } \\
\text { expensive method. }\end{array}$ & $\begin{array}{l}\text { Mokone and } \\
\text { Babalola (2013) }\end{array}$ \\
\hline $\begin{array}{l}\text { Seed } \\
\text { application }\end{array}$ & $\begin{array}{l}\text { Seeds are coated with } \\
\text { microbe-carrier slurry. } \\
\text { Adhesive solution such as } \\
\text { sucrose solution is } \\
\text { recommended. }\end{array}$ & $\begin{array}{l}\text { Adequate loading of bacterial } \\
\text { cells. Seeds treated with } \\
\text { microbial inoculants may } \\
\text { come in direct contact with } \\
\text { any seed applied with } \\
\text { chemicals which may } \\
\text { adversely affect the } \\
\text { survivability of the inoculated } \\
\text { organism. Microbial culture } \\
\text { may move away from rooting } \\
\text { zones after application and } \\
\text { could be exposed to } \\
\text { agrochemicals after planting } \\
\text { (Zaidi et al. 2014) }\end{array}$ & $\begin{array}{l}\text { Mokone and } \\
\text { Babalola (2013), } \\
\text { Babalola et al. } \\
\text { (2007), Babalola } \\
\text { (2010) and } \\
\text { Akladious and } \\
\text { Abbas (2012) }\end{array}$ \\
\hline $\begin{array}{l}\text { Seedling root } \\
\text { dip method }\end{array}$ & $\begin{array}{l}\text { The seedling root dip } \\
\text { method is mostly used for } \\
\text { transplanted crops like } \\
\text { vegetables. The roots of the } \\
\text { seedling are dipped in a } \\
\text { mixture of microbial } \\
\text { culture and water for } \\
5-10 \text { min. The seedlings is } \\
\text { then removed and } \\
\text { transplanted almost } \\
\text { immediately. }\end{array}$ & $\begin{array}{l}\text { A less expensive method } \\
\text { compare to carrier base } \\
\text { inoculants }\end{array}$ & $\begin{array}{l}\text { Babalola et al. } \\
\text { (2007) }\end{array}$ \\
\hline $\begin{array}{l}\text { Field/Soil } \\
\text { application }\end{array}$ & $\begin{array}{l}\text { The direct application of } \\
\text { inoculants to soil. } \\
\text { Generally the granular } \\
\text { inoculants are placed on } \\
\text { the furrow under or } \\
\text { alongside the seed. This } \\
\text { enhanced inoculated } \\
\text { microbe is in contact with } \\
\text { the plant root. }\end{array}$ & $\begin{array}{l}\text { less time consuming than the } \\
\text { seed inoculation method }\end{array}$ & $\begin{array}{l}\text { (Babalola et al. } \\
\text { 2007) }\end{array}$ \\
\hline $\begin{array}{l}\text { Broadcasting } \\
\text { method }\end{array}$ & $\begin{array}{l}\text { Microbial inoculants could } \\
\text { also be mixed with } \\
\text { farmyard manure before } \\
\text { broadcast. }\end{array}$ & $\begin{array}{l}\text { Rapid and greater } \\
\text { colonization of inoculants per } \\
\text { unit area }\end{array}$ & $\begin{array}{l}\text { (Akladious and } \\
\text { Abbas 2012) }\end{array}$ \\
\hline
\end{tabular}

O-antigenic aspect of lipopolysaccharide of Pseudomonas fluorescens WCS374 does not contribute to rhizosphere colonization. Other factors include; high microbial growth rate and the ability of the inoculants to produce vitamin B1 and exude nicotinamide adenine dinucleotide dehydrogenases (NADH) and their ability to secret site specific recombinase (Dennis et al. 2010). 
The association between inoculated culture and host plant play a vital role in determining the success of microbial inoculation technique in the field. More also, Different inoculants produce different level and types of organic acid. The organic acids also vary in their ability to form complexes with cations to release inorganic nutrients for plant use. For instance, the ability of organic acid to complex with cation and liberate inorganic phosphorus varies with oxalic and citric acid. Gluconic acid has a limited ability to chelate and release phosphorus complex with calcium. Other factors include: Physico-chemical properties of soil such as soil pH, organic matter content and moisture content, presence of environmental pollutants such as xenobiotics and composition of root exudates. Further, management practices such as irrigating; grooming and fertilizing also influence microbial activity and growth. To overcome these short comings, applications must occur at times when environmental conditions strongly favor activity of the inoculant and inoculant must be formulated in a way that favors its activity and survival. The fate of microbial inoculants under field application depends largely on both biotic and abiotic factors.

\subsection{Effects of Microbial Inoculants on the Resident Microbial Community}

In the inoculation of seed and soil large quantity of efficient and viable microbial cells are introduced to the soil to cause a rapid colonization of the host rhizosphere. This may greatly disturb the equilibrium of soil microbial communities (Babalola 2014). These changes could either be by reason of direct trophic competitions or because of antagonistic or synergetic interactions between the introduced microbes and the resident microbes. It could also be indirect effect mediated by enhanced root growth and exudation. These changes could be in the taxonomic group or in the functional capabilities of the soil microbial community.

Depending on the technique used to address the effect of microbial inoculants on soil microbial communities, microbial inoculation may cause tremendous changes in the composition and number of taxonomic groups. While some researchers reported a long term effect, some other ones observed a transient or no effect at all. Plant and soil are affected by both the temporal and long term effects of inoculants. These effects result in unpredictable reactions (Trabelsi and Mhamdi 2013). For instance, Probanza et al. (2002) observed alteration in microbial rhizosphere composition when Pinus pinea L was inoculated with Bacillus licheniformis CECT 5106 and Bacillus pumilus CECT105. Conn and Franco (2004) observed that the introduction of a non-adapted (mixed commercial inoculants) microbial inoculums to the soil cropped with wheat disrupted the natural actinobacterial endophyte population thus reducing the diversity and colonization level. In contrast addition of a single actinobacterial endophyte to wheat plant increase colonization level and the indigenous endophyte population was not adversely affected (Yousaf et al. 2011). When maize was inoculated with Azospirillum brasilense, according to 
Herschkovitz et al. (2005) the inoculants did not disrupt or alter the diversity and structure of root associated bacterial group both when universal bacterial primer and polymerase chain reaction (PCR)-denaturing gradient gel electrophoresis (DGGE) approach in conjunction with group-specific primers techniques were employed. The application some microbial inoculants could cause a change (which could be a decrease or an increase) in the equilibrium of soil microbial communities while some produce no effect at all.

\subsection{Conclusion}

This review has undoubtedly shown that microbial inoculants could improve biological management of nutrients and plant diseases resulting in improved plant performance in integrated plant management systems. They can contribute to a possible reduction of overuse of agro-chemicals and their environmental impacts. Though there are inconsistencies in the ability of many of the microorganisms that are used in the inoculant formulations to promote plant growth, the prospects of the inoculants like rhizobium, arbuscular mycorrhizal fungi and some rhizobacteria outweigh the lapses in meeting the goal of sustainable agricultural production. Apart from plant growth promotion, soil degradation is a serious problem in agriculture and the use of microbial inoculants is potentially part of the solution to this problem. More research effort is needed to elucidate the complex soil-plant-microbe interaction in order to reach the goal of completely substituting the environmentally degrading agro-chemicals with environmentally enhancing microbial inoculants. A combination of microorganisms in inoculant formulations has been shown to be helpful in many cases and can be made more efficient with research. Biotechnological research for effective and efficient microorganisms that are compatible with crops and adaptable to the soil environment will also be very helpful. In meeting the goal of sustainable agriculture, the use of microbial inoculants technology could be adopted for safe, increased production and sustainable agriculture.

Acknowledgements North-West University is gratefully acknowledged for ETA and MOD postdoctoral supports. OOB would like to thank the National Research Foundation, South Africa for grant (Ref: UID81192) that have supported research in her laboratory.

\section{References}

Abhilash PC, Srivastava S, Srivastava P, Singh B, Jafri A, Singh N (2011) Influence of rhizospheric microbial inoculation and tolerant plant species on the rhizoremediation of lindane. Environ Exp Bot 74:127-130. doi:10.1016/j.envexpbot.2011.05.009

Afzal M, Yousaf S, Reichenauer TG, Kuffner M, Sessitsch A (2011) Soil type affects plant colonization, and catabolic gene expression of inoculated bacterial strains during phytoremediation of diesel. J Hazard Mater 186:1568-1575. doi:10.1016/j.jhazmat.2010.12.040 
Afzal M, Yousaf S, Reichenauer TG, Sessitsch A (2012) The inoculation method affects colonization and performance of bacterial inoculant strains in the phytoremediation of soil contaminated with diesel oil. Int J Phytoremediation 14:35-47. doi:10.1080/15226514.2011.552928

Ahemad M, Kibret M (2014) Mechanisms and applications of plant growth promoting rhizobacteria: current perspective. J King Saud Univ Sci 26(1):1-20. doi:10.1016/j.jksus.2013.05.001

Akhtar MS, Shakeel U, Siddiqui ZA (2010) Biocontrol of Fusarium wilt by Bacillus pumilus. Pseudomonas alcaligenes, and Rhizobium sp. on lentil. Turk J Biology 34:1-7. doi:10.3906/ biy-0809-12

Akladious SA, Abbas SA (2012) Application of Trichoderma harziunum T22 as a biofertilizer supporting maize growth. Afr J Biotechnol 11(35):8672-8683. doi:10.5897/AJB11.4323

Alori ET (2015) Phytoremediation using microbial commmunity II. In: Ansari AA, Gill SS, Newman L, Lanza GR (eds) Phytoremediation: management of environmental contaminants, vol II. Springer Publications, New York, pp. 183-190. doi:10.1007/978-3-319-10969-5_15

Alori E, Fawole O (2012) Phytoremediation of soils contaminated with aluminium and manganese by two arbuscular mycorrhizal fungi. J Agric Sci 4(8):246-252. doi:10.5539/jas.v4n8p246

Ansari MF, Tipre DR, Dave SR (2014) Efficiency evaluation of commercial liquid biofertilizers for growth of Cicer aeritinum (chickpea) in pot and field study. Biocatal Agric Biotechnol 4(1):17-24. doi:10.1016/j.bcab.2014.09.010

Armada E, Portela G, Roldán A, Azcóna R (2014) Combined use of beneficial soil microorganism and agrowaste residue to cope with plant water limitation under semiarid conditions. Geoderma 232-234:640-648. doi:10.1016/j.geoderma.2014.06.025

Babalola OO (2010) Beneficial bacteria of agricultural importance. Biotechnol Lett 32(11):15591570. doi:10.1007/s10529-010-0347-0

Babalola OO (2014) Does nature make provision for backups in the modification of bacterial community structures? Biotechnol Genet Eng Rev 30(1):31-48. doi:10.1080/02648725.2014.9214 97

Babalola OO, Glick BR (2012) Indigenous African agriculture and plant associated microbes: current practice and future transgenic prospects. Sci Res Essays 7(28):2431-2439. doi:10.5897/ SRE11.1714

Babalola OO, Sanni AI, Odhiambo GD, Torto B (2007) Plant growth-promoting rhizobacteria do not pose any deleterious effect on cowpea and detectable amounts of ethylene are produced. World J Microbiol Biotechnol 23(6):747-752. doi:10.1007/s11274-006-9290-6

Barac T, Weyens N, Oeyen L, Taghavi S, van der Lelie D, Dubin D, Spliet M, Vangronveld J (2009) Field note: hydraulic containment of BTEX plume using poplar trees. Int J Phytoremediation 11:416-424. doi:10.1080/15226510802655880

Bargaz A, Faghire M, Abdi N, Farissi M, Sifi B, Drevon J-J, Ikbal MC, Ghoulam C (2012) Low soil phosphorus availability increases acid phosphatases activities and affects $\mathrm{P}$ partitioning in nodules, Seeds and Rhizosphere of Phaseolus vulgaris. Agriculture 2:139-153. doi:10.3390/ agriculture2020139

Becerra-Castro C, Prieto-Fernández Á, Kidd P, Weyens N, Rodríguez-Garrido B, ToucedaGonzález M, Acea MJ, Vangronsveld J (2013) Improving performance of Cytisus striatus on substrates contaminated with hexachlorocyclohexane $(\mathrm{HCH})$ isomers using bacterial inoculants: developing a phytoremediation strategy. Plant Soil 362:247-260. doi:10.1007/ s11104-012-1276-6

Bell CW, Acosta-Martinez V, Mcintyre NE, Cox S, Tissue DT, Zak JC (2009) Linking microbial community structure and function to seasonal differences in soil moisture and temperature in a Chihuahuan desert grassland. Microb Ecol 58:827-842. doi:10.1007/s00248-009-9529-5

Bernhard A (2010) The nitrogen cycle: processes, players, and human impact. Nat Educ Knowl 3(10): 25

Bossuyt H, Denef K, Six J, Frey SD, Merckx R, Paustian K (2001) Influence of microbial populations and residue quality on aggregate stability. Appl Soil Ecol 16:195-208. doi:10.1016/ S0929-1393(00)00116-5 
Calvo P, Nelson L, Kloepper JW (2014) Agricultural uses of plant biostimulants. Plant Soil 383(12):3-41. doi:10.1007/s11104-014-2131-8

Cao Y, Ling N, Yang XM, Chen LH, Shen QR (2011) Bacillus subtilis SQR9 can control Fusarium wilt in cucumber by colonizing plant roots. Biol Fertil Soils 47:495-506. doi:10.1007/ s00374-011-0556-2

Cardoso IM, Kuyper TW (2006) Mycorrhizas and tropical soil fertility. Agric Ecosyst Environ 116:72-84. doi:10.1016/j.agee.2006.03.011

Carvajal-Muñoz JS, Carmona-Garcia CE (2012) Benefits and limitations of biofertilization in agricultural practices. Livest Res Rural Dev 24(3)

Cavaglieri L, Orlando J, Rodriguez MI, Chulze S, Etcheverry M (2005) Biocontrol of Bacillus subtilis against Fusarium verticillioides in vitro at the maize root level. Res Microbiol 156:748754. doi:10.1016/j.resmic.2005.03.001

Chatzipavlidis I, Kefalogianni I, Venieraki A, Holzapfel W (2013) Status and trends of the conservation and sustainable use of microorganisms in agroindustrial processes. Food and Agricultural Organization (FAO) United Nations, United Nations

Conn VM, Franco CMM (2004) Effect of Microbial inoculants on the indigenous Actinobacterial Endophyte Population in the Roots of Wheat as Determined by Terminal Restriction Fragment Length Polymorphism. Appl Environ Microbiol 70(11):6407-6413. doi:10.1128/ AEM.70.11.6407-6413.2004

Cozzolino V, Di Meo V, Piccolo A (2013) Impact of arbuscular mycorrhizal fungi application on maize production and soil phosphorus availability. J Geochem Explor 129:40-44. doi:10.1016/j. gexplo.2013.02.006

Dare MO, Abaidoo RC, Fagbola O, Asiedu R (2010) Effects of arbuscular mycorrhizal inoculation and phosphorus application on yield and nutrient uptake of yam. Commun Soil Sci Plant 41:2729-2743. doi:10.1080/00103624,2010,518264

Davinic M, Moore-Kucera J, Acosta-Martínez V, Zak J, Allen V (2013) Soil fungal distribution and functionality as affected by grazing and vegetation components of integrated crop-livestock agroecosystems. Appl Soil Ecol 66:61-70. doi:10.1016/j.apsoil.2013.01.013

Dennis PG, Miller AJ, Hirsch PR (2010) Are root exudates more important than other sources of rhizodeposits in structuring rhizosphere bacterial communities? FEMS Microbiol Ecol 72:313-327. doi:10.1111/j.1574-6941.2010.00860.x

Demoz BT, Korsten L (2006) Bacillus subtilis attachment, colonization, and survival on avocado flowers and its mode of action on stem-end rot pathogens. Biol Control 37:68-74. doi:10.1016/J. Biocontrol.2005.11.010

Dhanasekaran D, Sivamani P, Panneerselvam A, Thajuddin N, Rajakumar G, Selva-mani S (2005) Biological control of tomato seedling damping off with Streptomyces sp. Plant Pathol J 4:91-95

Dimkpa C, Weinand T, Asch F (2009) Plant-rhizobacteria interactions alleviate abiotic stress conditions. Plant Cell Environ 321:682-1694. doi:10.1111/j.1365-3040.2009.02028.x

Egamberdiyeva D (2007) The effect of plant growth promoting bacteria on growth and nutrient uptake of maize in two different soils. Appl Soil Ecol 36:184-189. doi:10.1016/j. apsoil.2007.02.005

El-Tarabily KA, Nasser AH, Hardy GE, Sivaithamparam K (2008) Plant growth promotion and biological control of Pythium aphanidermatum, a pathogen of cucumber, by endophytic actinomycetes. J Appl Microbiol 106:13-26. doi:10.1111/j.1365-2672.2008.03926.x

Erdoğan O, Benlioğlu K (2010) Biological control of Verticillium wilt on cotton by the use of fluorescent Pseudomonas spp. under field conditions. BioControl 53:39-45. doi:10.1016/J. Biocontrol.2009.11.011

Errakhi R, Bouton F, Lebrihi A, Barakate M (2007) Evidence of biological control capacities of Streptomyces spp. against Sclerotium rolfsii responsible for damping-off disease in sugar beet (Beta vulgaris L.). World J Microbiol Biotechnol 23:1503-1509

Ferreira EM, Castro IV (2005) Residues of the cork industry as carriers for the production of legumes inoculants. Silva Lusitana 13(2):159-167 
Gaind S (2011) Microbial inoculants: an approach to sustainable agriculture. Biotech Article

Ganesan V (2008) Rhizoremediation of cadmium soil using a cadmium-resistant plant growthpromoting rhizopseudomonad. Curr Microbiol 56:403-407. doi:10.1007/s00284-008-9099-7

Germaine KJ, Keogh E, Ryan D, Dowling DN (2009) Bacterial endophyte-mediated naphthalene phytoprotection and phytoremediation. FEMS Microbiol Lett 296:226-234. doi:10.1111/j.1574-6968.2009.01637.x

Getha K, Vikineswary S, Wong WH, Seki T, Ward A, Goodfellow M (2005) Evaluation of Streptomyces sp. strain g10 for suppression of Fusarium wilt, rhizosphere colonization in potgrown banana plantlet. J Ind Microbiol Biotechnol 32:24-32. doi:10.1007/ s10295-004-0199-5

Golubev S, Schelud'ko A, Muratova A, Makarov O, Turkovskaya O (2009) Assessing the potential of rhizobacteria to survive under phenanthrene pollution. Water Air Soil Pollut 198:5-16. doi:10.1007/s11270-008-9821-X

Goudjal Y, Toumatia O, Yekkour A, Sabaou N, Mathieu F, Zitouni A (2014) Biocontrol of Rhizoctonia solani damping-off and promotion of tomato plant growth by endophytic actinomycetes isolated from native plants of Algerian Sahara. Microbiol Res 169:59-65. doi:10.1016/j. micres.2013.06.014

Halpern M, Bar-Tal A, Ofek M, Minz D, Muller T, Yermiyahu U (2015) The use of biostimulants for enhancing nutrient uptake. In: LS D (ed) Advances in Agronomy, vol 130. Academic Press, pp. 141-174. doi:10.1016/bs.agron.2014.10.001

Hamdali H, Hafidi M, Virolle MJ, Ouhdouch Y (2008) Growth promotion and protection against damping-off of wheat by two rock phosphate solubilizing actinomycetes in a P-deficient soil under greenhouse conditions. Appl Soil Ecol 40:510-517. doi:10.1016/j.apsoil.2008.08.001

Helliwell JR, Miller AJ, Whalley WR, Mooney SJ, Sturrock CJ (2014) Quantifying the impact of microbes on structural development and behaviour in wet soil. Soil Biol Biochem 74:138-147. doi:10.1016/j.soilbio.2014.03.009

Herschkovitz Y, Lerner A, Davidov Y, Okon Y, Jurkevitch E (2005) Azospirillum brasilense does not affect population structure of specific rhizobacterial communities of inoculated maize (Zea mays). Environ Microbiol 7(11):1847-1852. doi:10.1111/j.1462-2920.2005.00926.x

Hmaeid N, Metoui O, Wali M, Zorrig W, Abdelly C (2014) Comparative effects of Rhizobacteria in promoting growth of Hordeum maritimum L. plants under salt stress. J Plant Biol Res 3(1):37-50

Ho Y-N, Mathew DC, Hsiaoa S-C, Chun-Hao Shiha C-H, Chienb M-F, Chiang H-M, Huang C-C (2012) Selection and application of endophytic bacterium Achromobacter xylosoxidans strain F3B for improving phytoremediation of phenolic pollutants. J Hazard Mater. doi:10.1016/j. jhazmat.2012.03.035

Hodge A, Storer K (2015) Arbuscular mycorrhiza and nitrogen: implications for individual plants through to ecosystems. Plant Soil 383(1-2):1-19. doi:10.1007/s11104-014-2162-1

Hong S, Kim D, Baek S, Kwon S, Samson RA (2011) Taxonomy of Eurotium species isolated from meju. J Microbiol 49:669-674. doi:10.1007/s12275-011-0376-y

Huang X, Zhang N, Yong X, Yang X, Shen Q (2012) Biocontrol of Rhizoctonia solani damping-off disease in cucumber with Bacillus pumilus SQR-N43. Microbiol Res 167:135-143. doi:10.1016/J.Micres.2011.06.002

Hungaria M, Loureiro MF, Mendes IC, Campo RJ, Graham PH (2005) Inoculant preparation, production and application. In: Werner D, Newton WE (eds) Nitrogen fixation in agriculture, forestry, ecology and environment, vol 4. Springer, Netherlands, pp. 223-253. doi:10.1007/1-4020-3544-6_11

Jenkinson DA (2001) The impact of human on the nitrogen cycle with focus on temperate arable agriculture. Plant Soil 228:3-15. doi:10.1023/A:1004870606003

Jeong S, Moon HS, Shin D, Nam K (2013) Survival of introduced phosphate-solubilizing bacteria (PSB) and their impact on microbial community structure during the phytoextraction of Cd-contaminated soil. J Hazard Mater 263(2):441-449. doi:10.1016/j.jhazmat.2013.09.062 
Jha Y, Subramanian RB, Patel S (2011) Combination of endophytic and rhizospheric plant growth promoting rhizobacteria in Oryza sativa shows higher accumulation of osmoprotectant against saline stress. Acta Physiol Plant 33:797-802. doi:10.1007/s11738-010-0604-9

Julia WG, Peter H, Elizabeth L, Glen H (2013) Soil inoculants. University of Georgia College of Agricultural and Environmental Sciences, Cooperative Extension 10 pages

Karthikeyan B, Joe MM, Islam MR, Sa T (2012) ACC deaminase containing diazotrophic endophytic bacteria ameliorate salt stress in Catharanthus roseus through reduced ethylene levels and induction of antioxidative defense systems. Symbiosis 56:77-86. doi:10.1007/ s13199-012-0162-6

Kavino M, Harish S, Kumar N, Saravanakumar D, Samiyappan R (2010) Effect of chitinolytic PGPR on growth, yield and physiological attributes of banana (musa spp.) under field conditions. Appl Soil Ecol 45:71-77. doi:10.1016/j.apsoil.2010.02.003

Korade DL, Fulekar MH (2009) Rhizosphere remediation of chlorpyrifos in mycorrhizospheric soil using ryegrass. J Hazard Mater 172:1344-1350. doi:10.1016/J.Jhazmat.2009.08.002

Kruger M, Kruger C, Walker C, Stockinger H, Schubler A (2012) Phylogenetic reference data for systematics and phylotaxonomy of arbuscular mycorrhizal fungi from phylum to species level. New Phytol 193:970-984. doi:10.1111/j.1469-8137.2011.03962.x

Kuiper I, Lagendijk EL, Bloemberg GV, Lugtenberg BJJ (2004) Rhizoremediation: a beneficial plant-microbe interaction. Mol Plant Microbe Interact 17:6-15. doi:10.1094/MPMI.2004.17.1.6

Kumar B, Trivedi P, Pandey A (2007) Pseudomonas corrugata: a suitable bacterial inoculant for maize grown under rainfed conditions of Himalayan region. Soil Biol Biochem 39(12):30933100. doi:10.1016/j.soilbio.2007.07.003

Leifheit EF, Veresoglou SD, Lehmann A, Morris EK, Rillig MC (2014) Multiple factors influence the role of arbuscular mycorrhizal fungi in soil aggregation - a meta-analysis. Plant Soil 374:523-537. doi:10.1007/s11104-013-1899-2

Li Y, Zou YN, Wu QS (2013) Effects of inoculantion with Diversispora spurca on growth, root system architecture and chlorophyll contents of four citrus genotype plants. Int J Agric Biol 15:342-346

Liu D, Lian B, Dong H (2012) Isolation of Paenibacillus sp. and assessment of its potential for enhancing mineral weathering. Geomicrobiol J 29(5):413-421. doi:10.1080/01490451.2011.5 76602

Lucas ST, D'Angelo EM, Williams MA (2013) Improving soil structure by promoting fungal abundance with organic soil amendments. Appl Soil Ecol 75:13-23. doi:10.1016/j. apsoil.2013.10.002

Ma Y, Rajkumar M, Freitas H (2009) Inoculation of plant growth promoting bacterium Achromobacter xylosoxidans strain Ax10 for the improvement of copper phytoextraction by Brassica juncea. J Environ Manag 90:831-837. doi:10.1016/j.jvman.2008.01.014

Mokone PH, Babalola OO (2013) Evaluation of plant growth promoting potential of four rhizobacterial species for indigenous system. J Cent South Univ 20:164-171. doi:10.1007/ s11771-013-1472-4

Medina A, Roldán A, Azcón R (2010) The effectiveness of arbuscular-mycorrhizal fungi and Aspergillus niger or Phanerochaete chrysosporium treated organic amendments from olive residues upon plant growth in a semi-arid degraded soil. J Environ Manag 91:2547-2553. doi:10.1016/j.jenvman.2010.07.008

Meena VS, Maurya BR, Verma JP (2014) Does a rhizospheric microorganism enhance K+ availability in agricultural soils? Microbiol Res 169 (5-6):337-347. doi:http://dx.doi.org/10.1016/j. micres.2013.09.003

Mohammadi K, Khalesro S, Sohrabi Y, Heidari G (2011) A review: beneficial effects of the mycorrhizal fungi for plant growth. J Appl Environ Biol Sci 1(9):310-319

Moutia J-FY, Saumtally S, Spaepen S, Vanderleyden J (2010) Plant growth pro-motion by Azospirillum sp. in sugarcane is influenced by genotype and droughtstress. Plant Soil 337:233242. doi:10.1007/s11104-010-0519-7 
Muratova AY, Turkovskaya OV, Antonyuk LP, Makarov OE, Pozdnyakova LI, Ignatov V (2005) Oil-oxidizing potential of associative rhizobacteria of the genus Azospirillum. Microbiology $74: 210-215$

Naveed M, Mitter B, Reichenauer TG, Wieczorek K, Sessitscha A (2014) Increased drought stress resilience of maize through endophyticcolonization by Burkholderia phytofirmans PsJN and Enterobacter sp. FD17. Environ Exp Bot 97:30-39. doi:10.1016/j.envexpbot.2013.09.014

N'Cho CO, Yusuf AA, Ama-Abina JT, Jemo M, Abaidoo RC, Savane I (2013) Effects of commercial microbial inoculants and foliar fertilizers on soybean nodulation and yield in northern Guinea savannah of Nigeria. Int J Adv Agric Res 1:66-73

Negi PS, Chauhan AS, Sadia GA, Rohinishree YS, Ramteke RS (2005) Antioxidant and antibacterial activities of various seabuckthorn (hippophae rhamnoides 1.) seed extracts. Food Chem 92:119-124. doi:10.1016/j.foodchem.2004.07.009

Nivedhitha VR, Shwetha B, Deepa DD, Manojkumar NH, Raghavendra RB (2008) Plant growth promoting microorganisms (PGPMs) from bamboo rhizosphere. Adv Biotechnol:33-35

Oláh B, Brière C, Bécard G, Dénarié J, Gough C (2005) Nod factors and a diffusible factor from arbuscular mycorrhizal fungi stimulate lateral root formation in Medicago truncatula via the DMI1/DMI2 signalling pathway. Plant J 44:195-207

Oliveira T, Mucha AP, Reis I, Rodrigues P, Gomes CR, Almeida CMR (2014) Copper phytoremediation by a salt marsh plant (Phragmites australis) enhanced by autochthonous bioaugmentation. Mar Pollut Bull 88:231-238. doi:10.1016/j.marpolbul.2014.08.038

Ortiz N, Armada E, Duque E, Roldán A, Azcón R (2015) Contribution of arbuscular mycorrhizal fungi and/or bacteria to enhancing plant drought tolerance under natural soil conditions: Effectiveness of autochthonous or allochthonous strains. J Plant Physiol 174:87-96. doi:10.1016/j.jplph.2014.08.019

Owen D, Williams AP, Griffith GW, Withers PJA (2015) Use of commercial bio-inoculants to increase agricultural production through improved phosphrous acquisition. Appl Soil Ecol 86:41-54. doi:10.1016/j.apsoil.2014.09.012

Panwar BS, Kádár I, Bíró B, Rajkai-végh K, Ragályi P, Rékási M, Márton L (2011) Phytoremediation: Enhanced cadmium (Cd) accumulation by organic manuring, Edta and microbial inoculants (Azotobacter sp., Pseudomonas sp.) in Indian mustard Brassica juncea L). Act Agron Hung 59(2):117-123. doi:10.1556/AAgr.59.2011.2.2

Parmar P, Sindhu SS (2013) Potassium solubilization by rhizosphere bacteria: influence of nutritional and environmental conditions. J Microbiol Res 3(1):25-31. doi:10.5923/j. microbiology.20130301.04

Porras-Soriano A, Soriano-Martin ML, Porras-Piedra A, Azcón R (2009) Arbuscular mycorrhizal fungi increased growth, nutrient uptake and tolerance to salinity in olive trees under nursery conditions. J Plant Physiol 166:1359. doi:10.1128/AEM.71.12.8500-8505.2005

Paul D, Nair S (2008) Stress adaptations in a plant growth promoting Rhizobacterium (PGPR) with increasing salinity in the coastal agricultural soils. J Basic Microbiol 48:1-7. doi:10.1002/ jobm.200700365

Pereg L, McMillan M (2015) Scoping the potential uses of beneficial microorganisms for increasing productivity in cotton cropping systems. Soil Biol Biochem 80:349-358. doi:10.1016/J. Soilbio.2014.10.020

Probanza A, García JAL, Palomino MR, Ramos B, Mañero FJG (2002) Pinus pinea L. seedling growth and bacterial rhizosphere structure after inoculation with PGPR Bacillus (B. licheniformis CECT 5106 and B. pumilus CECT 5105). Appl Soil Ecol 20:75-84. doi:10.1016/ S0929-1393(02)00007-0

Rawat AK, Rao DLN, Sahu RK (2013) Effect of soybean inoculation with Bradyrhizobium and wheat inoculation with Azotobacter on their productivity and $\mathrm{N}$ turnover in a vertisol. Arch Agron Soil Sci 59(11):1559-1571. doi:10.1080/03650340.2012.740555

Reed MLE, Warner BG, Glick BR (2005) Plant growth-promoting bacteria facilitate the growth of the common reed Phragmites australis in the presence of copper or polycyclic aromatic hydrocarbons. Curr Microbiol 51(6):425-429. doi:10.1007/s00284-005-4584-8 
Rillig MC, Mummey DL (2006) Mycorrhizas and soil structure. New Phytol 171:41-53. doi:10.1111/j.1469-8137.2006.01750.x

Sadeghi A, Hessan AR, Askari H, Aghighi S, Shahidi BGH (2006) Biological control potential of two Streptomyces isolates on Rhizoctonia solani, the causal agent of damping-off of sugar beet. Pak J Biol Sci 9:904-910

Saharan BS, Nehra V (2011) Plant growth promoting rhizobacteria:a critical review. Life Sci Med Res 21:1-30

Sanderson RT (2014) Phosphorus (P) Chemica element. Encyclopedia Britannica

Sangeeth KP, Bhai RS, Srinivasan V (2012) Paenibacillus glucanolyticus, a promising potassium solubilizing bacterium isolated from black pepper (Piper nigrum L.) rhizosphere. J Spices Aromat Crops 21(2):118-124

Schwarze FWMR, Engels J, Mattheck C (2004) Fungal strategies of wood decay in trees. SpringerVerlag, Berlin

Shilev S, Sancho ED, Benlloch-González M (2012) Rhizospheric bacteria alleviate salt-produced stress in sunflower. J Environ Manag 95(Supplement):S37-S41. doi:10.1016/j. jenvman.2010.07.019

Shirmadi M, Savaghebi GR, Khavazi K, Akbarzadeh A, Farahbakhsh M, Rejali F, Sadat A (2010) Effect of microbial inoculants on uptake of nutrient elements in two cultivars of sunflower (Helianthus annuus L.) in saline soils. Not Sci Biol 2(3):57-66

Singh B, Satyanarayana T (2011) Microbial phytases in phosphorus acquisition and plant growth promotion. Physiol Mol Biol Plants 17:93-103. doi:10.1007/s12298-011-0062-x

Singh R, Soni SK, Patel RP, Kalra A (2013) Technology for improving essential oil yield of Ocimum basilicum L. (sweet basil) by application of bioinoculant colonized seeds under organic field conditions. Ind Crop Prod 45:335-342. doi:10.1016/j.indcrop.2013.01.003

Six J, Bossuyt H, Degryze S, Denef K (2004) Mycorrhizal Symbiosis. Soil Tillage Res 79:7-31

Smith SE, Read DJ (2008) Mycorrhizal Symbiosis, 3rd edn. Academic Press, London

Smith SE, Jakobsen I, Grønlund M, Smith FA (2011) Roles of arbuscular mycorrhizas in plant phosphorus nutrition: interactions between pathways of phosphorus uptake in arbuscular mycorrhizal roots have important implications for understanding and manipulating plant phosphorus acquisition. Plant Physiol 156:1050-1057. doi:10.1104/pp.111.174581

Trillas MI, Casanova E, Corxarrera L, Ordovas J, Borrero C, Aviles M (2006) Composts from agricultural waste, the Trichoderma asper-ellum strain T-34 suppress Rhizoctonia solani in cucumber seedlings. BioControl 39:32-38. doi:10.1016/j.biocontrol.2006.05.007

Sukweenadhia J, Kima Y, Choib E, Kohc S, Leed S, Kima Y, Yanga DC (2015) Paenibacillus yonginensis DCY84Tinduces changes in Arabidopsis thaliana gene expression against aluminum, drought, and salt stress. Microbiol Res 172:7-15. doi:10.1016/j.micres.2015.01.007

Taghavi S, Barac T, Greenberg B, Borremans B, Vangronsveld J, van der Lelie D (2005) Horizontal gene transfer to endogenous endophytic bacteria from poplar improves phytoremediation of toluene. Appl Environ Microbiol 71:8500-8505

Tank N, Saraf M (2010) Salinity-resistant plant growth promoting rhizobacteria ameliorates sodiumchloridestressontomatoplants.JPlantInteract5:51-58.doi:10.1080/17429140903125848

Teixeira C, Almeida MR, da Silva MN, Bordalo AA, Mucha AP (2014) Development of autochthonous microbial consortia for enhanced phytoremediation of salt-marsh sediments contaminated with cadmium. Sci Total Environ 493:757-765. doi:10.1016/j.scitotenv.2014.06.040

Trabelsi D, Mhamdi R (2013) Microbial inoculants and their impact on soil microbial communities: A review. BioMed Res Int:11. doi:10.1155/2013/863240

Trivedi P, Pandey A (2007) Application of immobilized cells of Pseudomonas putida to solubilize insoluble phosphate in broth and soil conditions. J Plant Nutr Soil Sci 170:629-631

Trivedi P, Pandey A, Palni LMS (2012) Bacterial inoculants for field applications under mountain ecosystem: present initiatives and future prospects. In: Maheshwari DK (ed) Bacteria in agrobiology: plant probiotics. Springer-Verlag, Berlin, Heidelberg, pp. 15-44. doi:10.1007/978-3-642-27515-9_2 
Veresoglou SD, Chen B, Rillig MC (2012) Arbuscular mycorrhiza and soil nitrogen cycling. Soil Biol Biochem 46:53-62. doi:10.1016/j.soilbio.2011.11.018

Vinocur B, Altman A (2005) Recent advances in engineering plant tolerance to abiotic stress: achievements and limitations. Curr Opin Biotechnol 16:123-132. doi:10.1016/j. copbio.2005.02.001

Wagner SC (2011) Biological nitrogen fixation. Nat Educ Knowl 3(10):15

Wang H, Liu S, Zhal L, Zhang J, Ren T, Fan B, Liu H (2015) Preparation and utilization of phosphate biofertilizers using agricultural waste. J Integr Agric 14(1):158-167. doi:10.1016/ S2095-3119(14)60760-7

White PJ, Karley AJ (2010) Potassium. In: Hell R, Mendel RR (eds) Cell biology of metals and nutrients, plant cell monographs, vol 17. Springer, Berlin, pp. 199-224

Wu HS, Yang XM, Fan JQ, Miao WG, Ling N, Xu YU, Huang QC, Shen Q (2009) Suppression of Fusarium wilt of watermelon by a bio-organic fertilizer containing combinations of antagonistic microorganisms. BioControl 54:287-295. doi:10.1007/s10526-008-9168-7

Wu Q-S, Srivastava AK, Zou Y-N (2013) AMF-induced tolerance to drought stress in citrus: a review. Sci Hortic 164:77-87. doi:10.1016/j.scienta.2013.09.010

Xiao K, Kinkel LL, Samac DA (2002) Biological control of Phytophthora root rots on alfalfa and soybean with Streptomyces. BioControl 23:285-295. doi:10.1006/Bcon.2001.1015

Xue C, Penton CR, Shen Z, Zhang R, Huang Q, Li R, Ruan Y, Shen Q (2015) Manipulating the banana rhizosphere microbiome for biological control of Panama disease. Sci Report 5:11124. doi:10.1038/srep11124

Yadav J, Verma JP (2014) Effect of seed inoculation with indigenous Rhizobium and plant growth promoting rhizobacteria on nutrients uptake and yields of chickpea (Cicer arietinum $\mathrm{L}$ ). Eur J Soil Biol 63:70-77. doi:10.1016/j.ejsobi.2014.05.001

Yang J, Kloepper J, Ryu C (2009) Rhizosphere bacteria help plants tolerate abiotic stress. Trends Plant Sci 14:1-4. doi:10.1016/j.tplants.2008.10.004

Yang XM, Chem LH, Yong XY, Zhana FG, Ran W, Shen QR (2011) Formulations can affect colonization and biocontrol efficiency of Trichoderma harzianum SQR-T037 against Fusarium wilt of cucumbers. Biol Fertil Soils 47:239-248. doi:10.1007/s00374-010-0527-z

Yousaf S, Afzal M, Reichenauer TG, Brady CL, Sessitsch A (2011) Hydrocarbon degradation, plant colonization and gene expression of alkane degradation genes by endophytic Enterobacter ludwigii strains. Environ Pollut 159(10):2675-2683. doi:10.1016/j.envpol.2011.05.031

Yuste JC, Peñuelas J, Estiarte M, Garcia-mas J, Mattana S, Ogaya R, Pujol M, Sardan J (2011) Drought-resistant fungi control soil organic matter decomposition and its response to temperature. Glob Chang Biol 17:1475-1486. doi:10.1111/j.1365-2486.2010.02300.x

Zaidi A, Khan MS, Ahmed E (2014) Microphos principles production and application strategies. In: Khan MS, Zaidi A, Musarrat J (eds) Phosphate solubilizing microorganism. Springer Cham Heidelberg, New York, pp 1-30

Zarjani JK, Aliasgharzad N, Oustan S, Emadi M, Ahmadi A (2013) Isolation and characterization of potassium solubilizing bacteria in some Iranian soils. Arch Agron Soil Sci 59(12):17131723. doi:10.1080/03650340.2012.756977

Zhu F, Qu L, Hong X, Sun X (2011) Isolation and characterization of a phosphate-solubilizing halophilic bacterium Kushneria sp. YCWA18 from Daqiao Saltern on the coast of yellow sea of China. Evid Based Complement Alternat Med:6. doi:10.1155/2011/615032 


\section{Index}

A

Abdelmageed, A.H.A., 50

Abida, S., 97-100

Agrawal, S.B., 115-147

Agricultural sustainability, 282, 284

Agrobacterium rhizogenes, 214, 235, 238

Agroforestry, 116, 310, 315, 319

Ahmad, A., 57-108

Ahmad, M., 99, 102

Ahmad, T., 73

Akbar, H., 99, 102

Akiyama, T., 192

Alamgir, A., 99

Ali, K., 57-108

Allen, D.J., 141

Alori, E.T., 281-300

Altman, A., 293

Amonette, J.E., 70

Anderson, J.A., 118

Animal waste, 1-10, 60, 61, 73

Aon, M., 57-108

Arbuscular mycorrhizal fungi, 16, 17, 25-28, $102,117,281,285,287-291,294,300$

Arif, M., 57-108

Ashcroft, W.J., 257

Azeem, M., 73, 77

\section{B}

Babalola, O.O., 281-300

Bagge, E., 7

Bailey, B., 41

Baille, A., 41

Balanced fertilization, 256, 271

Balwinder-Singh, 256, 259, 260

Banedjschafie, S., 271
Bano, A., 141

Bartzanas, T., 43

Basso, A.S., 76

Bhagat, R.M., 263

Biochar, 6, 57-108

Biochar technology, 81-89, 106, 107

Biocontrol, 194, 282-284, 295

Biofertilizer, 147, 282, 284, 287, 294

Biofuels, 9, 80, 213-239

Bioremediation, 216, 219, 220, 222, 223, 283

Biotechnology, 239

Biswas, B.C., 270

Borrel, A.K., 266

Boulard, T., 43-45

Bouman, B.A.M., 266

Bournet, P., 45

Bridgwater, A.V., 80

Bunemann, E., 24

C

Caba, J.M., 142

Cabangon, R.J., 269

Caldwell, M.M., 137

Chakraborty, D., 261

Chan, K.Y., 69, 77

Charbonneau, G.A., 142

Chaudhary, B.U., 266, 269

Chimphango, S.B.M., 135

Chitinase, 163-194, 295

Choudhary, K.K., 115-147

Choudhary, M.A., 268, 269

Chouhan, S., 135

Climate change, 73, 104, 106, 118, 290, 310, $314,318,320$

Conn, V.M., 299

E. Lichtfouse (ed.), Sustainable Agriculture Reviews, Sustainable Agriculture

Reviews 22, DOI 10.1007/978-3-319-48006-0 
Cooper, P.J.M., 255

Cossu, R., 1-10

Crop yields, 19, 29, 73-76, 99-103, 107, 108, $255,256,268,270,271,311,312$, 314-319, 321

\section{D}

da Silva, A.L.L., 213-239

Dana, M.M., 193

Dare, M.O., 281-300

Dempster, D.N., 77

Direct seeded rice, 256, 266, 269-270

Diversity, 17, 23-29, 215, 299, 300

Dryland agriculture, $72-80$

Duba, L.I., 145

Dullaart, J., 145

E

Environment, 3, 8, 10, 18, 29, 30, 38, 40, 45, $47,51,52,80,102,132,216,221-224$, 233, 236, 239, 260, 262, 269, 270, 282, 286, 300, 317-319, 321

Environmental services, 319

Erenstein, O., 264

F

Fan pad evaporative cooling, 42, 46-52

Fan, T., 271

Farooq, N.I., 100, 106

Fatnassi, H., 44, 45

Feedstock, 58-71, 77, 81-89, 96, 103-108, 237

Flint, S.D., 137

Food security, 254, 312, 314, 317, 318

Franco, C.M.M., 299

Fungal resistance, 185, 188

G

Gajri, P.R., 271

Gaskin, J.W., 69-70

Ghuman, B.S., 260

Gill, B.S., 260

Gill, M.S., 271

Girotto, F., 1-10

Glick, B.R., 294

Glucanase, 163-194

Gonzalez-Real, M,M., 41

Greenhouse microclimate, 38-42, 46, 48, 49, 52

Gruda, N., 50

Gupta, R.K., 265
H

Habibi, P., 213-239

Hadda, M.S., 253-272

Harper, J.E., 141

He, J., 139

He, X., 309-322

Hefferon, K., 213-239

Herschkovitz, Y., 300

Hira, G.S., 257

Hobbs, P., 265

Hughes, J.B., 220

Hussain, Q., 57-108

I

Insect, 6, 9, 42, 45, 48, 134, 174, 218, 228

Ippolito, J.A., 76, 77

Izaguirre, M.M., 140

J

Jalota, S.K., 260

Jansen, M.A.K., 140

Jat, M.L., 264, 268

Jha, Y., 293

Jospeh, S., 70

K

Kameyama, K., 76

Katyal, J.C., 270

Kaur, B., 268

Khan, A., 97-100

Khan, M.J., 97-100

Khan, N., 99

Khan, T.S., 98

Kittas, C., 43, 44, 46

Kostina, E., 138

Kubicek, C.P., 175

Kukal, S.S., 258

L

Laing, M., 37-52

Laird, D.A., 76

Laser land leveling, 256, 268-269

Latif, S., 57-108

Laube, J.C., 118

Legumes, 101, 116, 117, 132-146, 235, 286, 294, 316

Lehman, R.M., 15-30

Lehmann, J., 97

Leifheit, E.F., 290

Li, S., 46, 49 
Li, X., 64

Lin, L., 8

Liu, C.A., 271

Liu, X.H., 65

Lopez, A., 46

Lou, Y., 118, 132

\section{M}

Maboko, M.M., 41, 48-50

Mahimairaja, S., 65

Makhzoum, A., 213-239

Malik, R.K., 265

Malik, S., 213-239

Management, 3-9, 16, 17, 20, 23, 27-30, 41, $42,58,63,73,103,116,134,147,214$, 234, 253-272, 286, 288, 299, 300, 310, $315,316,318$

Maria Fatima Grossi De Sa, 213-239

Mashonjowa, E., 50

Max, F.J., 48, 49

Mian, I.A., 57-108

Microbial inoculants, 281-300

Mkonda, M.Y., 309-322

Mohammad, D., 99

Mulching, 259-262, 271, 272, 310, 314, 316-319

Mycorrhiza, 116, 117, 145, 147, 235, 284, 288,290

$\mathbf{N}$

Naeem, M.A., 64-70

Nair, S., 293

Natural ventilation, 42-45, 47-51

Nelissen, V., 64

Newcomb, W., 142

Newton, L., 9

Noorollahi, Y., 8

Novak, J.M., 77

O

Odindo, A., 37-52

Organic fertilization, 73, 318

Oshita, K., 8

Oz, H., 46

$\mathbf{P}$

Pakistan, 57-108

Pan, G., 57-108

Passioura, J., 255

Paul, D., 293
Phosphorus, soil microorganisms, 16-30

Phytoremediation, 213-239, 285, 291, 292

Plant growth, 16, 22, 24-26, 28, 38, 42, 69, $80,104,117,130,131,136,137,190$, 191, 222, 282-284, 286-289, 291, 293, 294, 296, 300

Plant growth promoting microorganisms (PGPM), 286

Plant hormones, 141-146, 282, 293

Plant molecular pharming, 228-234, 238, 239

Planting basins, 318

Prihar, S.S., 259

Probanza, A., 299

Pyrolysis, 6, 59, 60, 63-71, 76, 80-93, 95, 96, 103-105, 108

Q

Qayyum, M.F., 57-108

Qin, J., 261

Quilliam, 102

$\mathbf{R}$

Raised bed planting, 265-268

Rasul, F., 57-108

Recombinant proteins, 228-233

Relative humidity, 38, 41-48, 50, 51

Rezek, J., 223

Rhizobia, 116-119, 135, 144-147, 235, 284, 286, 287

Rillig, M.C., 290

Rodrigues, G.C., 140

S

Saghir, M., 57-108

Sajida, P., 97-100

Sakrabani, R., 57-108

Sandhu, B.S., 257, 258, 266

Sandhu, J.S., 163-194

Sandhu, S.S., 253-272

Santos, I., 138, 139

Sarkar, A.A., 257

Sasaki, C., 168

Sauer, T.J., 260

Secondary metabolites, 194, 214, 215, 224-228, 237, 295

Sela-Buurlage, M.B., 168, 184

Semi-arid, 37-52, 69, 73-75, 77, 80, $95,317,318$

Shackley, S., 57-108

Shah, H., 100, 106

Sharma, P.K., 263 
Shen, J.B., 271

Shenbagavalli, S., 65

Siddique, K.H.M., 260

Sidhu, H.S., 260

Sidhu, M.K., 163-194

Simpson, R.J., 20

Singh, A., 132

Singh, B., 66

Singh, D., 253-272

Singh, J., 253-272

Singh, K.B., 263

Singh, R.P., 264

Smith, J.L., 77

Soccol, C.R., 213-239

Sohi, S., 64

Soil fertility, 16, 22, 27-30, 58, 73, 92, 103, 105, 107, 119, 134, 270, 271, 286-289, $310,311,313-317$

Soil fertility and health, $282-300$

Soni, P., 44

Streubel, J.D., 76, 77

Su, Z., 267

Sudhir-Yadav, 270

Sur, H.S., 260

Sustainability, 107, 254, 282, 284, 289

Symbiosis, 26, 116, 118, 132-147

Szögi, A.A., 7

\section{T}

Taheri, W.I., 15-30

Takakura, Y., 184

Takeuchi, A., 141

Tanzania, 309-322

Teitel, M., 43, 44, 47-49

Temperature, 23-25, 38-52, 60, 64-71, $80-89,95,106,108,236,260,261$, 296, 310, 314

Tensiometer, 258

Terraces, 310, 316, 319
Tewatia, R.K., 270

Thipe, E.L., 37-52

Transgenic plants, 164, 184-190, 192, 193, 227-229, 232, 233, 235, 237, 239

Transgenic roots, 235, 239

Tuong, T.P., 266

$\mathbf{U}$

Ultraviolet-B (UV-B), 115-147

V

Van Aalten, D.M.F., 168

Van den Noort, R.E., 140

Vinocur, B., 293 von

Elsner, B., 41 von

Zabeltitz, C., 41

W

Water productivity, 254-261, 263-265, 268-271

Willits, D.H., 46, 49

Workneh, T., 37-52

Wu, H., 8

Wulff, A., 138

Y

Yadav, I.S., 163-194

Yuste, J.C., 290

$\mathbf{Z}$

Zhang, J.H., 64

Zhang, X.C., 65

Zhu, F.X., 9

Zhu, K., 6 